NASA Technical Memorandum 83564

\title{
Performance Degradation of a Typical Twin Engine Commuter Type Aircraft in Measured Natural Icing Conditions
}

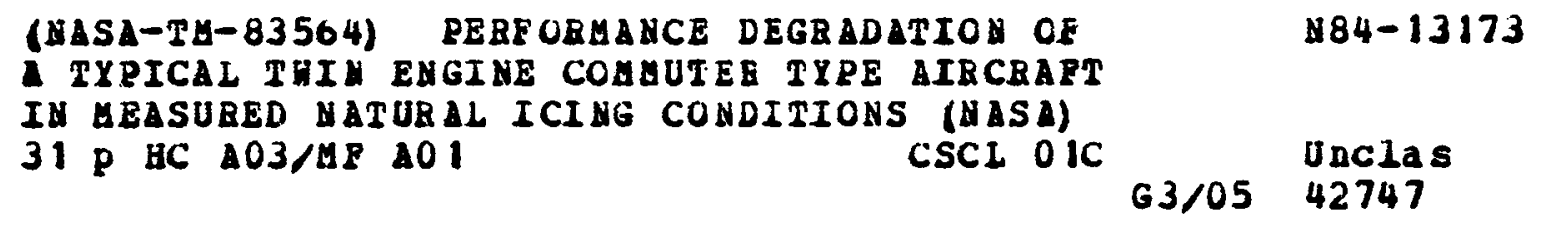

Richard J. Ranaudo, Kevin L. Mikkelsen, and Robert C. McKnight

Lewis Research Center

Cleveland, Ohio

and

Porter J. Perkins, Jr.

Analex Corporation

Dayton, Ohio

Prepared for the

Twenty-second Aerospace Sciences Meeting

sponsored by the American Institute of Aeronaut $\because$ and Astronautics Reno, Nevada, January 9-12, 1984

\section{nusn}


PERFORMANCE DEGRADATION OF A TYPICAL TWIN ENGINE COMMUTER TYPE AIRCRAFT IN MEASURED NATURAL ICING CONDITIONS

Richard J. Ranaudo, Kevin L. Mikkelsen, and Robert C. McKnight National Aeronautics and Space Administration

Lewis Research Center

Cleveland, onio 44135

and

Porter J. Perkins, Jr.

Analex Corpoiation

5335 Far Hills Ave.; Suite 222

Dayton, Ohio 45429

Summary

This paper deals with the initial results of the NASA Lewis Research Center's flight research in quantifying the performance of an aircraft in various measured icing conditions. Flight research performed in natural icing conditions supports a number of major program elements at NASA. 1 One of tnese elements is to develop

F analytical methods (computer codes) that predict

i aircraft perforinance degradation in a given icing condition. A major problem in developing these codes has been the lack of an experimental data base where measurements of the natural icing environment were associated with a corresponding measurement of aircraft performance degradation.

Icing parameters such as liquid water content, temperature, cloud droplet sizes, and ice accretions were measured with icing instruments mounted on the research aircraft. Continuous on-line reading of these instruments provided a quantitative display of the icing environment. Thus, when icing was detected the extent of the icing could be monitored and controlled by holding within the icing area.

Following each measured icing encounter, level flight speed/power runs were made from maximum obtainable level flight speed to a speed just above stall. When possible, repeat runs were made after selectively deicing the wings and empennage. Flight data were reduced to provide plots of the aircraft drag polar for the measured "iced" condition and a lift curve $\left(C_{L}\right.$ vs. a) as referenced to the uniced or clean airframe baseline. in order to determine the effect of icing on engine-out performance capability, these data were also reduced to provide plots of thrust horsepower required vs. single engine power ayailable.

Aircraft perforinance measurements are referenced to those characteristics of the icing condition that created the ice accretions. Performance degradation is primarily influenced by the amount and silupe of the accumulated ice. The amount of ice was ineasured but shape was not quantitatively determined. In addition to presenting specific values of the icing variables, the icing encounters were characterized in terms of their relation to frequency of occurrence and the FAA icing cloud criteria for ice protection systems.

This paper is declared a work of the U.S.

Government and therefore is in the public domain.
Glaze icing caused the greatest aerodynamic performance/penalties in terms of increased drag and reduction in lift. Rime icing provided proportionately lower aerodynamic performance penalties.

Data acquired through this flight test prom gram will provide a basis to develop aircraft perforinance prediction codes for icing conditions. One such code is being developed under a NASA Lewis Research Center grant by the Ohio State University. The geometry of the icing research aircraft, along with the measured icing environment and corresponding aircraft performance degradation data, will be used to provide a basis for the development of this code.

\section{Introduction}

The NASA Lewis Research Center is conducting an aircraft icing research prograrn. Flight testing is performed in natural icing conditions to support several major program elements. I Among these elements are flight. experiments that provide ice accretion shape and attendant aerodynamic drag data for validating computer codes and the Lewis Icing Research Tunnel (IRT). Other elenents of the flight program involve the evaluation of current icing instrumentation, 2 the collection and documentation of icing cloud meteorological data, and the measurement of aircraft performance degradation due to icing. This paper will address the latter element by presenting our initial experimental results in quantifying the perforinance degradation of a twin engine commuter type aircraft in measurres natural icing conditions. Included in these data are the measured contribution of the wings and tail group to the overall drag of the iced aircraft. These data will be used to verify computer codes currently under development, that predict the degradation of aircraft performance in icing conditions. 3

A major problem in developing these codes has been the lack of an experimental data base where comprehensive aircraft performance measurements were made along with corresponding measurements of the icing environment. In this regard some 1 imited efforts were made in the past 4,5 but the resulting data lacked eitner complete documentation of the icing cloud variables, and/or comprehensive measurerents of derodynamic perforinance penalties due to ice accretions. In this flight 
test program, several icing instruments were employed to measure icing cloud variables. Data from these instruments were then used to characterize each icing encounter relative to the measured icing cloud variables, and to Federal Air Regulation (FAR) Part 25 Appendix $C$ certification criteria. 6 After each measured icing encounter rigorous level-flight speed/power performance flight testing was accomplished with the icing research aircraft (fig. 1a) to determine the increase in aircraft drag coefficient and the reduction in aircraft lift coefficient due to ice. Additional speed/power runs were then made after selectively deicing the wings and tail group to further determine component drag contributions to overall aircraft drag.

Eight out of eleven icing research flights provided reportable data; however, to avoid unnecessary repetition and to focus in on key observations and results, three flights, each representing unique icing encounters are presented herein.

\section{Instrumentation}

\section{Icing Cloud Parameters}

Measurements were made of cloud liquid water content, cloud droplet size distribution, volume median diameter, air temperature, ice accretion rate, and duration of the icing encounters. Photographs were taken in flight of the ice accretions on the outboard section of the wing leading edge and of other airframe components visible from the cockpit and cabin.

Instrumentation included:

For liquid water content: Johnson and Williams $(J-W)$ heated wire ${ }^{7}$ produced by Cloud Technology (fig. 2(a));

For cloud droplet size distribution and volume median diameter: rotating multicylinder 8 (fig.2(b));

For air temperature: platinum resistance total temperature probe ${ }^{9}$ produced by Rosemount (fig. 2(c));

For ice accretion: Pressure-type Icing Rate and Accretion Meter (PIRAM) 10 developed by NACA (fig $2(d))$.

\section{Aircraft Performance Ir.strumentation}

All aircraft performance measurements were made with calibrated service system instruments. The only insirument used that was not a part of the ship's service system was the heated angle of attack probe. These instruments included:

Engine Torque:

Edison Torque Pressure Gage $\left(1 \mathrm{~b} / \mathrm{in}^{2}\right)$

Propeller RPM:

General Electric (percent)

Pressure Altitude: Aerosonic Encoder $(\mathrm{ft})$

Indicated Airspeed: Bendix Pioneer (knots)

\section{Angle of Attack: Specialties, Inc. (units/deg)}

Engine shaft horsepower (SHP) was calculated according to a simple equation in the aircraft flight manual using torque pressure and propeller RPM. Thrust horsepower was obtained by imultipying calculated SHP by propeller efficiency. Aircraft weight was deterinines by adding the fuel remaining at test condition to the zero fuel weight of :l:? aircraft.

\section{Flight Test Procedures}

Baseline perforinance in terins of an aircraft drag polar was obtained for the icing research aircraft in clear air by enploying level flight performance test methods. 11,12,13 Numerous data points were obtained for the instrumented aircraft. A lift curve and drag polar were derived to establish a baseline for lift and drag coefficient comparisons between the iced vs. un-iced airplane. All instruments used to measure aircraft performance were bench calibrated for instrument errors. The service airspeed and altitude system were flight calibrated for static source position error. 14 Propeller efficiency for each performance data point was calculated from a propeller efficiency chart supplied to NASA by The Hartzel Division of TRW, Inc.

All airframe icing was accreted at a nominal cruise flight condition, i.a., a cruise airspeed of approximately 125 KIAS (150 to 160 inph true airspeed). While in icing, the aircraft was kept "on condition" by adjusting power to maintain a constant cruise airspeed throughout the icing encounter. While the aircraft was allowed to ice up, icing instrumentation cont inually measured liquid water content, icing rate, total ice accretion, temperature, and cloud water droplet sizes and distribution. Camleras were used to photograph ice shapes as the aircraft progressed through the icing encounter and while level flight aircraft performance measurements were made. The pneumat ic wing and tail deicer boots were not activated during the icing encounter; however, propeller and engine inlet heaters were always kept on to insure that full aircraft power was always available if needed. After a sufficient allount of ice had been accreted on the airframe, the aircraft would be flown to exit the icing area as quickly as possible. Generally the quickest ineans was to climb above the icing cloud.

At this point level flight speed/power runs were flown (using the same procedures as in the clear air baseline tests) first with the aircraft all iced, excepting the propellers and engine inlets. A second and third speed/power series were then successively flown with wings and tail deiced respectively to establish the drag contribution of each airframe component. Figure 1b shows these portions of the airframe that are protected by deicing systems. Residual ice remaining on the wings and tail surfaces was not photographically documented since all portions of these surfaces were not visible from the cockpit or cabin. Elevators, allerons, and rudder were trimned for each data point. If the aircraft began shedding ice during the course of a speed/ power series, the series would be abandoned. Speed/power series were not attempted between 
successive icing encounters unless the airframe could be totally deiced prior to each new icing encounter. In addition, speed/power series were not at tempted unless flight conditions were smooth. All level flight performance measurements were made from maximum level flight speed to stall buffet onset with the flaps up. No performance measurements were made with any degree of flaps down. At the speeds and temperatures encountered during the relatively short period of time when level flight performance measurements were made, sublimation rates of ice were judged to be negijnibly small and had no appreciable effect on the
data.

\section{Results and Discussion}

Data pertaining to the results and discussion for each of the three selected icing research flights are contained in Tables I to III. Date, time, airspeed, and altitude for each icing encounter are given in Table I. Basic icing cloud variables and those properties of the ice accretions that influence aircraft performance degradation are given in Table II. Aircraft performance degradation in terms of drag polar curve fits are summarized in Table III.

Figure 3 is included to show the variability and peak values of liquid water content measured during each of the three selected icing encounters. Continuous plots from recorded indications of the heated wire probe are shown in Fig. 3 for each of the three icing encounters. Values were recorded once per second in flight, but the arithmetic average over a 10-second period was used to establish each point on the plots.

Figures $4(a)$ to (c), display icing data for each flight relative to FAR 25 Appendix $C$ certification criteria, while the remaining figs. 5 to 15 show lift curve, drag polar, and power-velocity plots of aircraft performance with ice as compared
to the uniced baseline.

\section{Characterization of Icing Encounters as Related to}

A ircraft performance measurements taken following an icing encounter are referenced to those characteristics of the icing condition that created the ice accretions. Performance de radation is primarily influenced by (1) the amount of ice accumulated and by (2) the shape of the ice that formed. The quantity of ice collectr. is mainly a function of the cloud liquid...er content, the extent of the icing cloud, :he droplet size distribution, and volume mediar diameter. Temperature may partly determine the amount collected if close to freezing. The shape of the ice formation is influenced by the rate of freezing. Low temperatures and water concentrations with small droplets promote rapid freezing producing rather smooth and pointed ice accretions (rime $i c e)$. Temperatures near freezing and higher accretion rates (1 iquid water content $x$ airspeed) with larger droplet =izes result in delays in freezing, creating irregular ice formations with flat or concave surfaces ( $g$ laze ice) facing the airstream. The ice shape that forms is of extreme importance since the contours and location of the ice formations on the various aircraft components significantly affect the aerodynamic performance, particularly aircraft 1 ift and drag. Unfortunately, empirical relationships correlat ing the aerodynamic performance degradation of individual airfrante components with ice accretions from icing encounters 15 are presently not in existence. Until valid computer codes are available, the deleterious effects can only be determined by flight tests of each type of aircraft in natural conditions as is reported herein for one class of airplane.

For this reason, aircraft performance data in this report is associated only with the available icing environment observations and measurements. which are presented in Table II under two categories; the basic icing cloud variables and the properties of the ice accretions. Measured cloud variables include liquid water content, droplet size distributions, median volume diameter, temperature, and the duration and extent of the icing. Ice accretion properties include icing rate, amount of ice accreted, and the shape of the ice formation as determined by observation.

Frequency of Occurrence. - An approach to categorizing the severity of an icing encounter is to relate that encounter to the frequency of its occurrence. Ali the pertinent icing encounter parameters that determine intensity (LWC, extent of icing, droplet size distribution, median volume diameter, and air temperature) should be treated in combination in assessing the probability of exceeding the intepsity of a specific condition. Lewis and Bergrun analyzed statistically all the available data obtained in icing flights up to that time (1952) and presented these data in probability charts. In one approach, plots are provided to determine the probability of equaling or exceeding any specified value of LWC under the condition that the value is associated simultaneously with values of temperature and drop diameter lying within specified intervals. The plots are based on preselected values of horizontal extent. Thus, all the icing encounter parameters associated with intensity are considered.

These probability plots were used to associate the severity of the icing conditions reported here in with the previously determined icing statistics. For each icing flight the measured value of average $L W C$ occurring simultaneously with the other measured icing parameters are used with the plots to determine what the chances are in normal flight operations of equaling or exceeding that Specific LWC value. For example, the LWC measured in flight $83-9\left(0.35 \mathrm{gms} / \mathrm{m}^{3}\right)$ would be equaled or exceeded in only $i$ out of 250 icing encounters when formed in combination with the other measured icing parameters (see table II). This low probability stems primarily from the unusual duration of the icing produced by the procedure of nolding with in the icing clouds.

FAA Ice Certification Criteria. - For inany years the extremities of fcing conditions were gauged by the FAR Part 25 icing parameter envelopes used to design and certify ice protection systems. Thus, icing characteristics of a given icing encounter can be related to these envelopes. Figure 4 from FAR Part 25 gives the maximum liquid water content to be found continuously in stratiforin clouds as related to mean effective drop diameter, air temperature, and cloud horizontal 
extent. This FAR envelope of maximum conditions is for a standard distance of 20 miles (17.4 Nautical Miles). For icing encounter distances other than the standard distance, the maximum liquid water content may be increased or decreased depending on whether the encounter distance is shorter or longer than the standard distance. Data have shown that the more localized a cloud formation, the higher will be its liquid water content. A variable factor relating maximum liquid water content with horizontal distance has been developed from previous data. The maximum liquid water content is modified by mult iplying values of liquid water content for the standard distance by the appropriate factor determined for the actual distance flown in icing. For example, the actual horizontal extent of the icing encounter for flight 83-9 was 72 N.M. The liquid water content factor for this distance would be 0.55 , and the maximum liquid water cont int would be decreased by that amount. As shown in fig. $4(a)$, the dotted line for maximum LWC at $-4,4^{\circ} \mathrm{C}$ (interpolated value) is moved downward as given by the solid line in this figure. Thus the measured liquid water content of encounter 83-9 becomes closer to the maximum ( 81 percent of max.) than if compared to the standard distance. Figures $4(\mathrm{~b})$ (flight 83-10) and $4(\mathrm{c})$ (flight 83-11), respectively, were constructed by employing the same procedure. Results from these figures are also contained in Table II.

The variable factor relating LWC with distance is of primary interest in determining the amount of ice which can accumulate on unprotected surfaces during an icing encounter (Reference Total Accretion, table II). However, for design of ice protection systems, the maximum LWC for the standard distance (17.4 N.M.) is used.

\section{Aircraft Performance Degradation}

Eight of eleven icing research flights provided aircraft performance degradation data over a range of icing conditions; however, the results of only three selected flights are discussed herein. Overall aircraft lift coefficient decreases and drag coefficient increases were documented for each measured natural icing encounter. Contributions of the iced wing and tail group to the flight test measured changes in aircraft lift coefficient $\left(C_{L}\right)$ and drag coefficient $\left(C_{D}\right)$ were successfully identified by making level flight performance measurements after each of these components were selectively deiced. Iced aircraft performance data in terms of resulting drag polars and lift curves were compared to the uniced aircraft performance baseline to quantitatively determine how ice accretions affected aircraft drag, aircraft 1 ift coefficier.t, and wing efficiency factor (e). The uniced aircraft performance baseline is shown in Figs. $5(a)$ and $5(b)$.

Power/velocity plots were also developed to approximate the magnitude of icing effects on engine-out performance. These plots were constructed by comparing the two engine flight derivell equivalent weight thrust horsepower (THPEW) required curves for the uniced vs. iced aircraft against a calculation of one-engine THP available. This plot of one engine THP available was calculated by using (1) max continuous power setting charts in the Pilot's Handbook for 100 percent propeller RPM at sea level and 96 percent
RPM at any altitude, and (2) propeller efficiency charts to calculate the propeller efficiencies which are used to obtain THP. It should be noted that the two engine power required curves shown do not exactly represent the single engine case because trim drags caused by dsyminetric thrust are
not included.

Photographs of ice shapes that had accreted on various portions of the aircraft at the time each perforinance measurement was inade were obtained in flight with hand-held cameras. A group of photographs that include the wing leading edge and other representative airframe components visible from the cockpit or cabin are listed by research flight number and contained in Figs. 6 to 8. Table II contains a description of these ice types and shapes.

As mentioned previously, only three of the eight icing research flights are discussed in detail. Research flights 83-9,83-10, and 83-11 were selected for discussion as each one presented a unique icing situation: 83-9 was flown in glaze icing conditions that were 81 percent of maximum LWC (adjusted for horizontal distance) in the FAR 25 appendix $C$ icing certification envelope and therefore represented a relatively severe icing encounter; 83-10 provided the best complete set of aerodynamic and measured environmental parameters for a glaze ice encounter; 83-11 provided the same quality of data as 83-10, but for a rime ice encounter. Also note that flight 83-11 was flown in conditions that were calculated to be 104 percent of the maximum LWC in the FAR 25 Appendix $C$ criteria. This fact provided some interesting comparisons between glaze and rime icing from an derodynamic perforinance standpoint.

Research Flight 83-9. - The $C_{L}$ vs. a plot for 83-9 (fig. 9(a)), shows that ice affected the aircraft lift curve considerably. At $a=6^{\circ}$, for example, the "all-iced" aircraft lift coefficient is 17 percent lower than the uniced baseline. However, when the horizontal and vertical tail $p 1$ anes were deiced, the 1 ift coefficient at $\alpha=6^{\circ}$ is 10 percent lower than the uniced baseline. This indicates that with the tail surfaces deiced the $C_{L}$ vs. a curve shifts upward towards the baseline. A similar observation was made on another research flight (not shown in this report) where the tail surfaces were deiced first and a corresponding set of aircraft performance measurements made. The upward shift in the lift curve may be attributed to the recovery of elevator effectiveness after ice is removed from the leading edge of the horizontal tail plane. The implication here is that ice on the leading edge of the horizontal tail reduces elevator ef fectiveness, and for a given aircraft weight, center of gravity, and configuration, increases level flight trim speed. Unfortunately, since elevator position and aircraft center of gravity were not precisely known at the time, there is insufficient information available to address this observation further. Future research flights will incorporate tests to examine this phenomenon more closely.

The Covs. Cf arag polar for flight 83-9 (fig. $9(\mathrm{~b})$ ), shows relative drag increase for both the "ali-iced" and "tall-only deiced" condition. Additional component deicing of the wings was not completed since ice began to shed from the airframe immediately after the tail-deiced speed 
power series was finished. A least squares $f$ it of the "all-iced" data for flight 83-9 shows a very substantial increase in total aircraft drag. For example, at $C^{2}=0.25$, aircraft drag increased approximately 62 percent over baseline. When the horizontal and vertical tails were deiced, the "all-iced" drag was reduced by 16 percent. Note that these percentage values will vary somewhat over the attainable range of lift coefficients. Also note that the four "all-iced" data points represent the "compressed" range of attainable lift coefficients between maximum level flight speed and onset stall buffet. When only the tail group is deiced, this envelope expands considerably. The changes in parasitic drag coefficient and wing efficiency factor for this flight are summarized in Table III.

Research Flight 83-10. - This flight yielded the best glaze ice data both from an environmental and aerodynamic standpoint. With the aircraft "dll-iced" the $C_{l}$ vs. a plot ( $f$ ig. 10(a)) again shows the effects of ice on lift coefficient reduction. At a $=6^{\circ}$, for example, there is an approximate 16 percent ioss in $C_{L}$. After deicing the wings (excluding the nondeiceable portion between the fuselage and engine nacelles as shown in fig. $1(b))$, the $c_{L}$ loss is approximately 4 percent at $a=6^{\circ}$. Subsequent deicing of the horizontal and vertical tail planes does not appear to provide any appreciable improvement. Note that even with both wings and tail deiced, the lift curve always remains below the baseline. There are two possible explanations:

1) The resulting lift curve reflects the loss in $C_{L}$ due to ice remaining on the portion of wings between the fuselage and engine nacelles, i.e., the non-deiceable portion of the wings.

2) The small amount of residual ice left alung the wing after pneumatic boot activation may provide sufficient contamination to degrade lift coefficient.

The complete reason for this observed phenomena is probably due to a combination of both factors.

The drag polars derived for this flight are shown in Fig. 10(b). Choosing a $C^{2}$ of 0.25 , $\left(C_{L}=0.5\right)$, the aircraft drag coefficient is approximately 45 percent higher than baseline at that point. When the wings are deiced (except the non-deiceable portion), the aircraft drag coefficient is reduced to 33 percent above baseline. When the horizontal and vertical tail planes are deiced, the drag coefficient is 28 percent above baseline. Note that approximately 60 percent of the increased drag due to ice still remains after deicing both wings and tail. This is due to ice accretions that cannot be removed, i.e., ice that accretes on non-protected surfaces such as struts, antennae, hinge brackets, etc.

The drag polar equations resulting from a least squares curve $f$ it of the data are shown in Table III. The wing efficiency factor " $e$ " and parasitic drag coefficient may be extracted from these equations to quantify aerodynamic affects. Note the value of "e" for the "all-iced" airplane in comparison to the uniced baseline value. The decrease in wing efficiency factor is responsible for the steeper slope of the "all-iced" drag polar in Fig. 10(b). For this case, the wing is only 53 percent as efficient as the uniced wing. After deicing the wing, "e" is still only 84 percent as efficient as the uniced wing. Again this is probably due to the combination of incomplete ice removal by the pneumatic boots, and ice remaining on those portions of the wing between the fuselage and nacelle. The nondeiceable portion of the wings is approximately 20 percent of the total span excluding the portion of the wing behind the engine nacelle and fuselage. When the tail group is deiced, it is interesting to note that wing efficiency improves to 95 percent of the baseline value.

Research Flight 83-11. - This flight yielded the best rime ice data from both the environmental and aerodynamic standpoint. Referring to Fig. 8 , note how much smoother the accreted rime ice shapes are in comparison to the glaze ice shapes encountered on flights 83-9 and 83-10 (figs. 6 and 7). Also note that in referring to the environmental data for flights 83-10 and 83-11 (table II), nearly the same average LWC's $(.31$ and .29 $\mathrm{gm} / \mathrm{m}^{3}$, respectively) were obtained; however, the icing encounter in 83-11 was approximately 40 percent longer than that for 83-10. Yet the aerodynamic affects measured were entirely different.

On the $C_{L}$ vs. a plot for flight 83-11, Fig. 1la, the same characteristic degradation in lift slope is observed as in flight 83-10. However, the magnitude of this degradation is less severe.

A comparison of the resulting drag polars from flights 83-10 (fig. $10(\mathrm{~b})$ ), and 83-11 (fig. $11(b))$, shows an interesting contrast in results. On flight 83-11, for example, at a $C^{2}=0.25$, the "all-iced" drag polar displays an approximate 15 percent aircraft drag increase as opposed to a 45 percent aircraft drag increase obtained on flight 83-10 at the same value $C$. Even though flight 83-11 was flown through icing at nearly the same LWC as flight 83-10, and the time of encounter was 77 percent longer, the drag increase was only $1 / 3$ as great. Indeed, the "all-iced" rime condition encountered on 83-11 provides less aircraft drag than the "wings and tail deiced" case on 33-10. Referring to the tabulated drag polar equations for flights 83-10 and 83-11 in Table III. the parasitic drag coefficlent $\left(C_{D O}\right)$ for the "all-iced" case in flight 83-11 is 17 percent at ve the uniced baseline while the "wing and tail deiced" case in 83-10 is 25 percent above the uniced baseline. It is also difficult to infer how wing efficiency factor " $e$ " changed with this icing condition since the inagnitude of the drag measurements appeared to fall within the range of scatter norinally achieved. However, the main conclusion to draw from Flight 83-11 as opposed to Flights $83-9$ and $83-10$ is the much lower lift and drag penalties incurred in rime icing versus glaze icing.

Engine-0ut Capability. - Figure 12 shows the baseline uniced thrust horsepower required for standard day, standard weight, and sea level conditions. Figures $13(\mathrm{a}), 14(\mathrm{a})$, and $15(\mathrm{a})$ were plotted to show approximate engine out capability for the icing research aircraft for standard day, standard weight, and sea-level conditions. Figures 13(b), 14(b), and 15(b) were plotted to show 
engine-out capability for standard weight, at test altitude conditions. As previously discussed, these plots are somewhat idealized. Extrapolation of the data for flight 83-9, Fig. 13a, shows that with no deicing capability, the aircraft would have to descend if an engine were to fail. However, just by deicing the horizontal and vertical tail, a rather limited single engine capability exists at sea level on a standard day at standard gross weight. Referring now to fig. $13 \mathrm{~b}$, we see how, at a pressure altitude of 6000 feet, deicing capability of the tail group alone is not sufficient to reduce drag to the point where level flight could be maintained. Unfortunately, this particular test was abandoned before the wings could be selectively deiced, so the extent of improvement can not be determined. Based upon test results from other flights, e.g. 83-10, it appears that the amount of drag that is lost when the wings are deiced is twice the amount lost when the tail group only is deiced (see fig. 10b). This would lead one to qualitatively observe that at 6000 feet pressure altitude on flight 83-9, full deicing of the wings and tail would have recovered engine-out capability from the fully iced condition.

Flights 83-10 and 83-11 occurring at 6000 feet and 6500 feet, respectively, are included to provide comparisons between engine-out capability for glaze and rime ice conditions (see figs. 14b and 15b). It can be seen that a large amount of rime ice can accumulate on an aircraft before engine-out capability suffers. Conversely, it appears that only a small amount of glaze ice will rapidly erode that capability. Nonetheless, these plots, though somewhat idealized, illustrate the importance of developing aircraft performance prediction methodologies that can adequately address both anti-ice/deice systems requirements for both normal cperations and in terms of failure modes analysis. In addition, these methodologies could also be used to provide valuable flight manual information to pilots in terms of aircraft perforinance limitations during icing encounters.

\section{Conclusions}

Icing can be characterized with respect to those conditions that caused the ice accretions including (1) the basic icing cloud variables such as liquid water content, droplet size distributions, volume median diameter, temperature, and extent of the icing cloud and (2) the properties of the ice accretions such as ice type, shape, icing rate, and reference total accretion. Aircraft performance can then be associated with these parameters or displayed with more familiar criteria such as FAR 25 appendix $C$ icing certification requirements.

Glaze icing, which generally occurs at total air temperatures just below freezing, results in iough, irregular ice formations with flat or concave surfaces facing the airstream. This type of icing generally causes the largest aircraft performance penalties in terms of loss in aircraft lift, and increase in aircraft drag. Depending on icing rates under these conditions, aircraft drag can increase measurably in relatively short periods of time (less than $30 \mathrm{~min}$ ) with attendant losses in climb rate and/or engine out capability. Aircraft with many non-deiceable components such as struts, landing gear, hinge brackets, anternae, and other small protuberances as are found on the Lewis icing research aircraft, can retain bo60 percent of the total accumulated drag even after deicing the wings and tail group.

Rime icing which generally occurs at lower total air temperatures below freezing, results in smoother, more pointed ice formations facing the airstream. This type of icing generally causes much lower lift and drag penaities as compared to similar amounts of glaze ice. This result is illustratef by comparing a rime icing research flight (83-11) to a glaze icing research flight (83-10) where approximately tine same LWC's were encountered at the same airspeeds. Even though Flight 83-11 encountered icing 77 percent longer than flight 83-10, the drag increase for Fight 83-11 was only one-third as great as that measured on Flight 83-10.

\section{Future Efforts}

This paper sresents experimental results on aircraft performance in measured natural icing conditions. Additional aircraft performance related experiments will be employed in future research flights to include:

1. The employment of stereo photography to quantitatively document ice shapes that form on the wing and sther airframe components.

2. The use of a heated wake survey probe to measure section drag across the iced aircraft wing. Combining this capability with stereo photography of the same section of aircraft wing will estab? ish the basis for computer codes development and IRT correlative experiments.

3. Employment of a pressure belt to measure un-iced wing section lift coefficient. These data in conjunction with wake survey probe results will be used to establish aerodynamic conditions for wing section tests that will be run in the NASA-LERC IRT.

4. Measurement of icing research aircraft elevator control position and angle of attack with a capability to vary center of gravity to determine how ice accretions affect the basic aircraft static longitudinal stability coefficients.

\section{References}

1. Reininann, J.J., Shaw, R.J., and 01sen, W.A. Jr., "NASA Lewis Research Center's Program on Icing Research," NASA TM-83031, 1983.

2. Ide, R. F., and Richter, G. P., "Evaluation of Icing Cloud Instrumentation for 1982-83 lcing Season Flight Program," AIAA 84-0020, Jan. 1984.

3. Gregorek, G.M., Bragg, M.D., and Shilling, J.B., "Performance Analys is for Aircraft in Icing Conditions," AIAA 84-0180, Jan. 1984. 
4. Preston, G.M., and Bl ackman, C.C., "Effects of Ice Formations on Airplane Performance in Level Cruising Flight", NACA TN-1598, 1948.

5. Leckman, P.R., "Qualification of Light Aircraft for Flight in Icing Conditions," SAE Paper 710394, Mar. 1971.

6. "Ice Protectiun," Airworthiness Standards Transport Category Airplanes, F.A.A. Regulations Part 25, Section 25.1419, Appendix C, 1974.

7. Neel, C.B., Jr., and Steinmetz, C.P., "The Calculated and Measured Performance Characteristics of a Heated-Wire Liquid-WaterContent Meter for Measuring Icing Severity," NACA TN-2615, 1952.

8. Brun, R.J., Lewis, W., Perkins, P.J., and Serafini, J.S., "Impingement of Cloud Droplets on a Cyl inder and Procedure for Measuring Liquid-Water Content and Droplet Sizes in Supercocled Clouds by Rotating Multicylinder Method," NACA TR-1215, 1955.

9. Lewis, W., "A Flight Investigation of the Meteorclogical Conditions Conducive to the Formation of ICe on Airplanes," NACA TN-1393, 1947.

10. Perkins, P.J., McCullough, S., and Lewis, R.D. "A Simplified Instrument for Recording and Indicating Frequency and Intensity of Icing Conditions Encountered in Flight," NACA RM-E51E 16, 1951.

11. Lush, K.J., and Moakes, J.K., "Performance Reduct ion Methods for Turbo-Propeller Aircraft," pp. 5:1-20; Dommasch, D.0., "Data Reduction and Performance Test Methods for Reciprocating Engine Aircraft," pp. 6:1-26, AGARD Flight Test Manual, Vol. I, edited by E.J. Durbin and C.D. Perkins, 2nd revised ed., Pergamon Press, Oxford, 1962.

12. Smith, H.C., "Introduction to Aircraft Flight Test Engineering," Pennsylvania State University, University Park, PA, July, 1974, Pp. 14-45.

13. Sma11, S.M., and Prueher, J.W., "Fixed Wing Performance: Theory and Flight Test Techniques," USNTPS-FTM-104, July, 1977, pp VII-18 - VII-25

14. Fisher, B.D., Holmes, B.J., anu Stough, H.P. III, "A Flight Evaluation of a Trailing Anemometer for Low Speed Calibrations of Airspeed Systems on Research Aircraft," NASA TP-1135, 1978 .

15. Gray, V.H., "Prediction of Aerodynamic Penalties Caused by Ice Formations on Varlous Airfoils," NASA TN D-2166, 1964.

16. Lewis, W. and Bergrun, N.R., "A Probability Analys is of the Meteorological Factors Conducive to Aircraft Icing in the United States," NACA TN-2738, 1952.

APPENDIX A

EXPLANATION OF TABLE II

ICING CLOUD DATA AND ACCRETION PROPERTIES

Heading

1. Static

Temperature

( $\mathrm{C}$ )

2(a). Average LWC (gms./cu m)

2(b). Maximum LWC (gms./cu m)

3(a). Duration of Encounter (min.)

3(b). Extent of Encounter (Nautical miles)

4(a). Median Volume Droplet Dia.

4(b). Droplet Size Distribution

4(c). Maximum Droplet Dia. (microns)

5. Cloud Type

\section{Explanation}

Static air temperature derived from total air temperature measurements. If variable, average value is shown.

An arithmetic average of individual readings at equal intervals of time

The peak LWC of the icing encounter measured over a distance of about 2.6 nautical miles. This relates the encounter to the intermittent maximum certification criteria of FAR Part 25.

Time in minutes from start of icing to end of encounter as measured by icing instruments.

Duration of encounter $x$ true airspeed.

An average value of droplet size (microns)for for the encounter. A rotating multicylinder exposure is self averaging providing a representative value and because of method is called Mean Effective Droplet Dia.

Because rotating multicylinders are used, the Langmuir distribution designation $(A-J)$ is shown.

In the droplet size distribution, the droplet size at which about 5 percent of the tota? liquid water is in larger droplet sizes. (This value is useful in determining the ared of maximum impingement on large surfaces - wing, and aiso influences ice shapes).

Either stratiform ciouds (continuous) or cumuliform clouds (intermittent). This relates the encounter to the FAR Part 25 certification criteria. 
6. Type of Ice

\section{Shape of Ice \\ 8. Average Ice Accretion Rate (in./hr.)}
9. Reference Total Ice Accretion (inches)

Trins common ly used to describe ice accretions such as Rime, Glaze, Clear, and Mixed.

A single word description obtained from wing photos.

Obtained from ice accretion instrument (Avg. Ice ACC. Rate $=$ Number of icing cycles for encounter $x .020 /$ Total accumulated time of each icing cycle).

Thickness of ice formed on small sensing probe at end of icing encounier. Measured by ice accretion instrument (Ref. Total Ice ACC. = Avg. Ice ACC. Rate $X$ Duration of the Encounter).
10. Characterization of lcing Encounter

(a). Frequency of A means of referencing occurrence this icing encounter to previously determined probability that has established, for any random icing encounter, the probability that the measured LWC of this encounter would be exceeded. A chart given in NACA TN 2738 is used to determine the probability value.

(b). Certification This icing encounter is Criteria

related to the icing parameter envelopes given in FAR Part 25 Appendix C. Value shown is the measured LWC as a percent of the maximum value given in the FAR envelope corrected for horizontal distance. 
TABLE I. - ICING ENCOUNTER FLIGHT DATA

\begin{tabular}{|l|c|c|c|c|}
\hline $\begin{array}{l}\text { Flight } \\
\text { number }\end{array}$ & Date & $\begin{array}{c}\text { Begin } \\
\text { time, } \\
\text { EST }\end{array}$ & $\begin{array}{c}\text { True } \\
\text { airspeed, } \\
\text { mph }\end{array}$ & $\begin{array}{c}\text { Pressure } \\
\text { altitude, } \\
\text { ft }\end{array}$ \\
\hline $83-9$ & $3 / 11 / 83$ & $10: 46 \mathrm{~A}$ & 138 & 4700 \\
$83-10$ & $3 / 21 / 83$ & $10: 14 \mathrm{~A}$ & 157 & 4500 \\
$83-11$ & $3 / 21 / 83$ & $3: 07 \mathrm{P}$ & 159 & 5500 \\
\hline
\end{tabular}


TABLE II. - ICING CLOUD DATA AND ACCRETION PROPERTIES FOR ICING FLIGHTS

[See appendix $A$ for definitions.]

\begin{tabular}{|c|c|c|c|}
\hline Flight number & $83-9$ & $83-10$ & $83-11$ \\
\hline \multicolumn{4}{|c|}{ Icing cloud data } \\
\hline $\begin{array}{l}\text { 1a. Total temperature }\left({ }^{\circ} \mathrm{C}\right) \\
\text { 1b. Static temperature }\left({ }^{\circ} \mathrm{C}\right) \\
\text { 2a. Average LWC (gms/cu } \mathrm{m} \text { ) } \\
\text { 2b. Maximum LWC (gms/cu m) } \\
\text { 3a. Duration of encounter (min.) } \\
\text { 3b. Extent of encounter (naut. miles) } \\
\text { 4a. Median volume droplet diameter (microns) } \\
\text { 4b. Droplet size distribution } \\
\text { 4c. Maximum droplet size (microns) } \\
\text { 5. Cloud type }\end{array}$ & $\begin{array}{c}-3.2^{\circ} \\
-4.4^{\circ} \\
0.35 \\
0.80 \\
36 \\
72 \\
-\ldots- \\
-\cdots \\
\text { Strato- Cu }\end{array}$ & $\begin{array}{l}-2.3^{\circ} \\
-4^{\circ} \\
0.31 \\
0.45 \\
26 \\
59 \\
13 \\
\text { E } \\
35 \\
\text { Strato-Cu }\end{array}$ & $\begin{array}{c}-8.9^{\circ} \\
-10.6^{\circ} \\
0.29 \\
0.53 \\
46 \\
106 \\
13 \\
D \\
29 \\
\text { Strato-Cu }\end{array}$ \\
\hline \multicolumn{4}{|c|}{ Ice accretion properties } \\
\hline $\begin{array}{l}\text { 6. Type of ice (see photo) } \\
\text { 7. Shape of ice (see photo) } \\
\text { 8. Average accretion rate (in./hr) } \\
\text { 9. Reference total accretion (in.) } \\
\text { 10. Characterization of icing } \\
\text { a. Frequency of occurrence } \\
\text { b. Certification criteriaa }\end{array}$ & $\begin{array}{c}\text { Glaze } \\
\text { Double } \\
\text { ridged } \\
2.68 \\
1.61\end{array}$ & $\begin{array}{c}\text { Glaze } \\
\text { Double } \\
\text { rldged } \\
3.32 \\
1.44\end{array}$ & $\begin{array}{l}\text { Rime } \\
\text { Curved } \\
3.80 \\
2.91\end{array}$ \\
\hline
\end{tabular}

apercent of $\max$ LWC. 
TABLE III. - CURVE FITS OF DRAG DATA

\begin{tabular}{|c|c|c|}
\hline & $C_{D}$ & e \\
\hline \multicolumn{3}{|c|}{ Clean hircraft } \\
\hline $\begin{array}{l}\text { Straight line least squares } \\
\text { fit of range } 0<c_{L}^{2} \leq 1.0 \\
\text { Third order fit of complete } \\
\text { range }\end{array}$ & $\begin{array}{l}0.045+0.0414 c_{L}^{2} \\
0.0452+0.0423 c_{L}^{2} \\
-0.01 c_{L}^{4}+0.0096 c_{L}^{6}\end{array}$ & 0.7635 \\
\hline \multicolumn{3}{|c|}{ Flight $83-9$} \\
\hline $\begin{array}{l}\text { All lced } \\
\text { Talls delced }\end{array}$ & $\begin{array}{r}0.0747+0.0588 c_{L}^{2} \\
.0712+.0512 c_{L}^{2}\end{array}$ & $\begin{array}{r}0.5382 \\
.5175\end{array}$ \\
\hline \multicolumn{3}{|c|}{ Flight $83-10$} \\
\hline $\begin{array}{l}\text { All iced } \\
\text { Wings deiced } \\
\text { Wings and Talis deiced }\end{array}$ & $\begin{array}{r}0.0609+0.0782 C_{L}^{2} \\
.0613+.0492 C_{L}^{2} \\
.0597+.0438 C_{L}^{2}\end{array}$ & $\begin{array}{r}0.4045 \\
.6435 \\
.7224\end{array}$ \\
\hline \multicolumn{3}{|c|}{ Filght $83-11$} \\
\hline $\begin{array}{l}\text { All lced } \\
\text { Wings defced } \\
\text { Wings and Talls deiced }\end{array}$ & $\begin{array}{r}0.0525+0.0432 c_{L}^{2} \\
.0482+.0494 c_{L}^{2} \\
.0465+.0555 c_{L}^{2}\end{array}$ & $\begin{array}{r}0.7315 \\
.6399 \\
.5703\end{array}$ \\
\hline
\end{tabular}


$\therefore \quad$ in

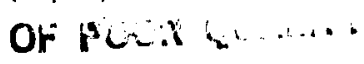
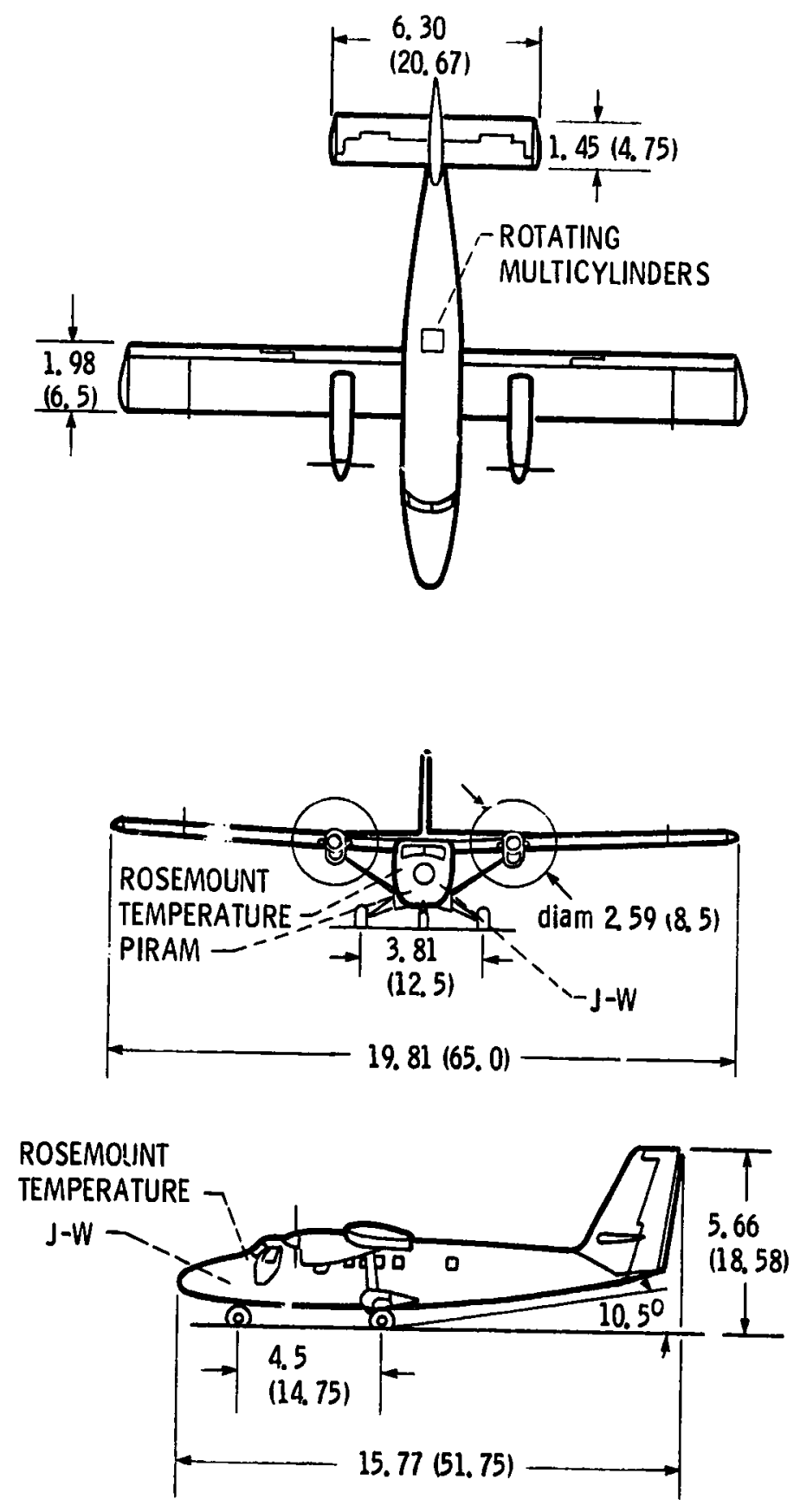

Figure 1a. - NASA Lewis Research Center icing research aircraft and icing instrument locations. All dimensions are in $\mathrm{m}$ (ft). 


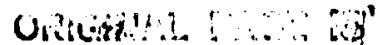 \\ OF POOR QUALITY.}

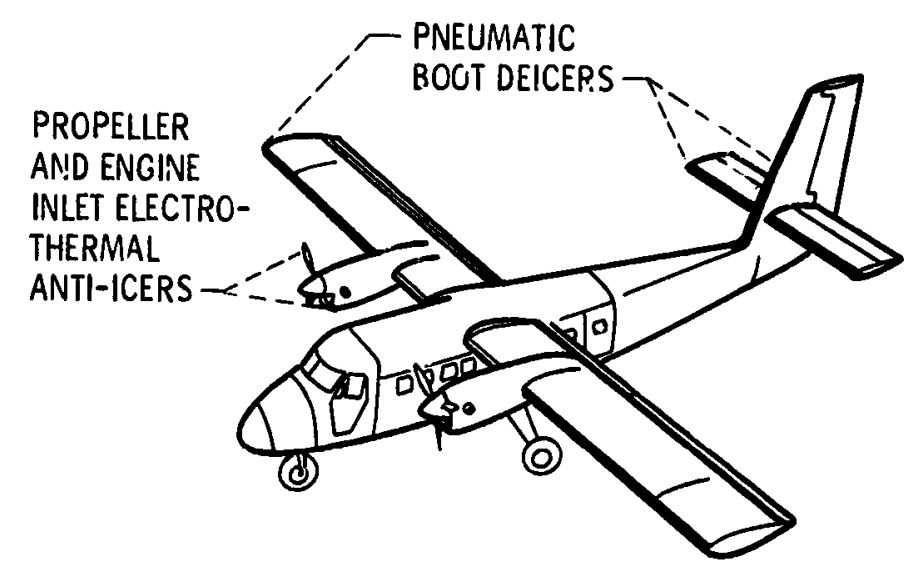

Figure 1b. - Icing research aircraft showing areas protected by anti-icing/deicing equipment.

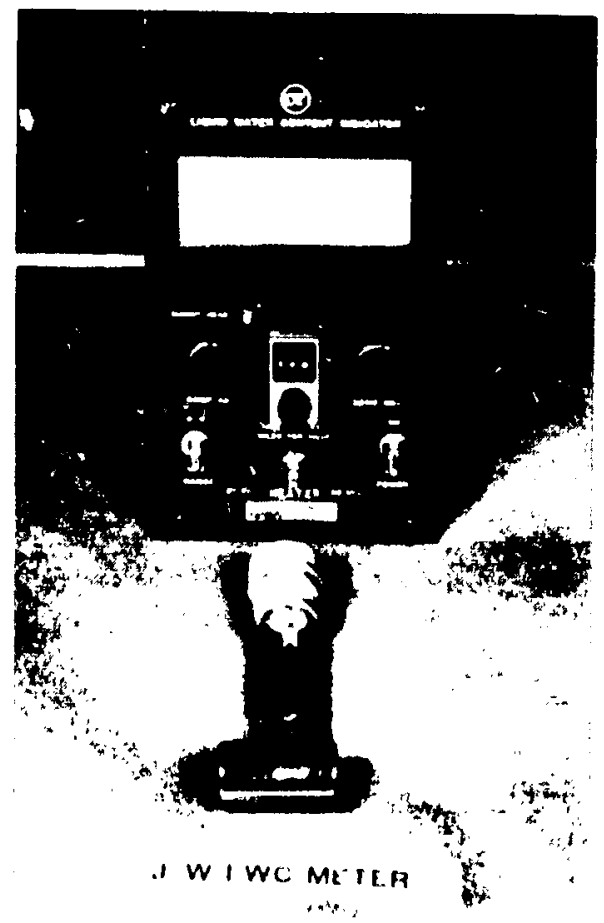

(a) Johnson Williams heated wire for measuring LWC.

Figure 2. - Icing cloud instrumentation. 


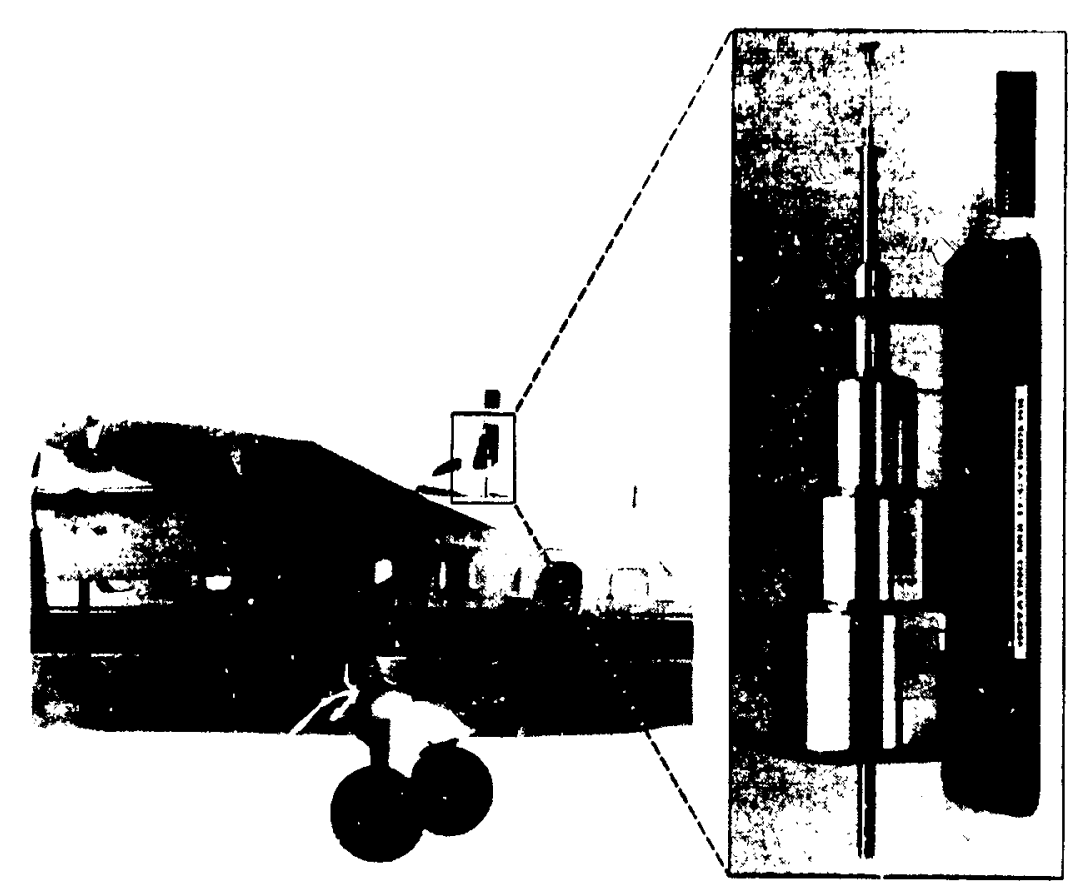

(b) Rotating multi-cylinder for measuring water droplet size distribution. Figure 2. - Continued.

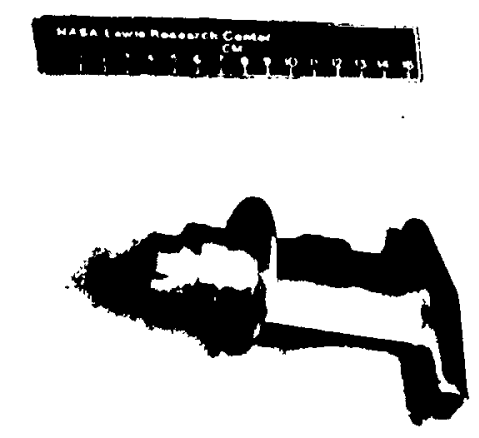

ROSEMOUNT OAT PROBE

(c) Rosemount total air temperature probe for measuring air temperature.

Figure 2. - Continued. 


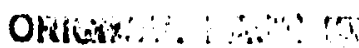

OF Foch Quntity
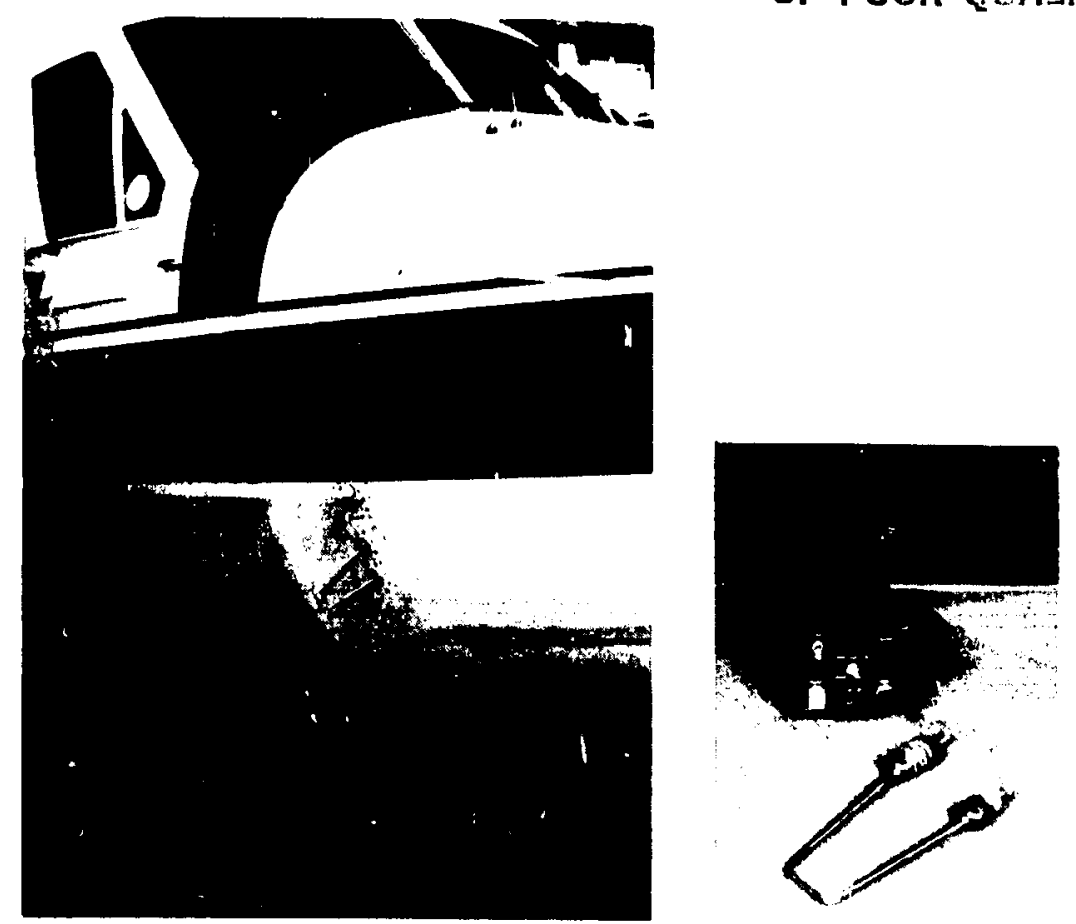

(d) PIRAM for measuring reference ice accretion rates and total accretion. Figure 2. - Concluded.

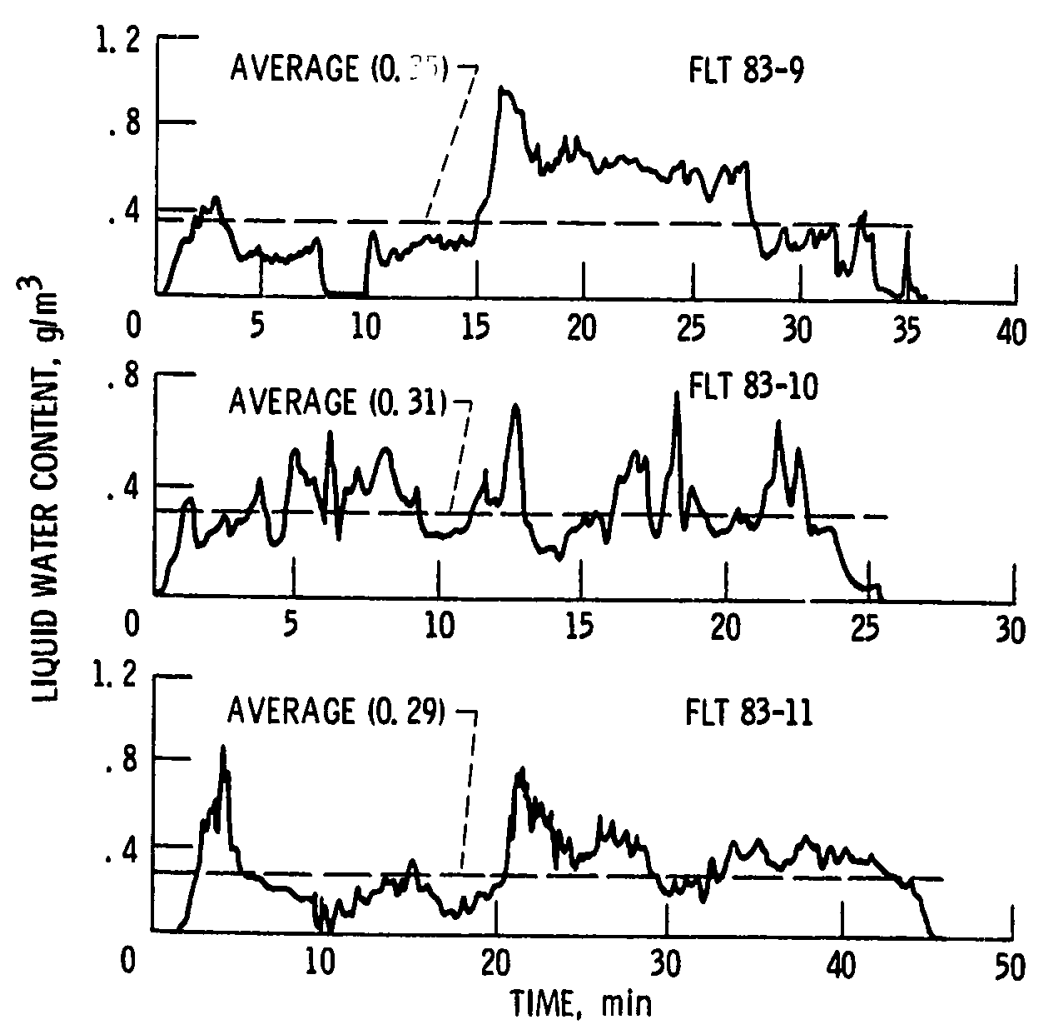

Figure 3. - Variation of liquid water content, (LWC) with time for each icing research flight. 
ranos

or Hon guarri
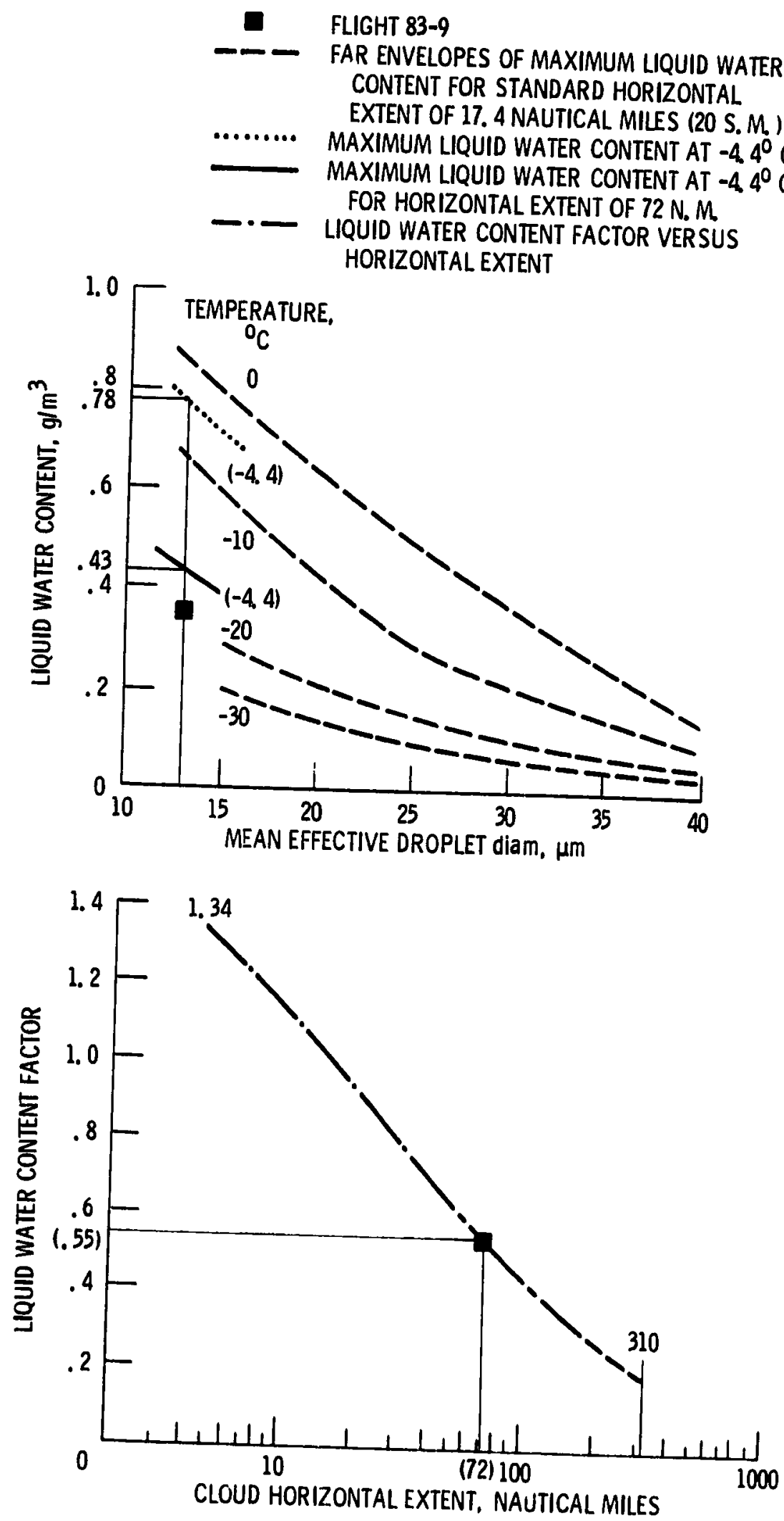

Figure 4a. - Flight 83-9 superimposed on FAR appendix $C$ of part 25 continuous maximum (stratiform clouds). 
- FLIGHT 83-10

- - FAR ENVELOPES OF MAXIMUM LIQUID WATER CONTENT FOR STANDARD HORIZONTAL EXTENT OF 17. 4 NAUTICAL MILES (20 S. M.) MAXIMUM LIQUID WATER CONTENT AT $-5^{\circ} \mathrm{C}$

- MAXIMUM LIQUID WATER CONTENT AT $-5^{\circ} \mathrm{C}$ FOR HORIZONTAL EXTENT OF 59 N. M.

- - LIQUID WATER CONTENT FACTOR VERSUS HORIZONTAL EXTENT
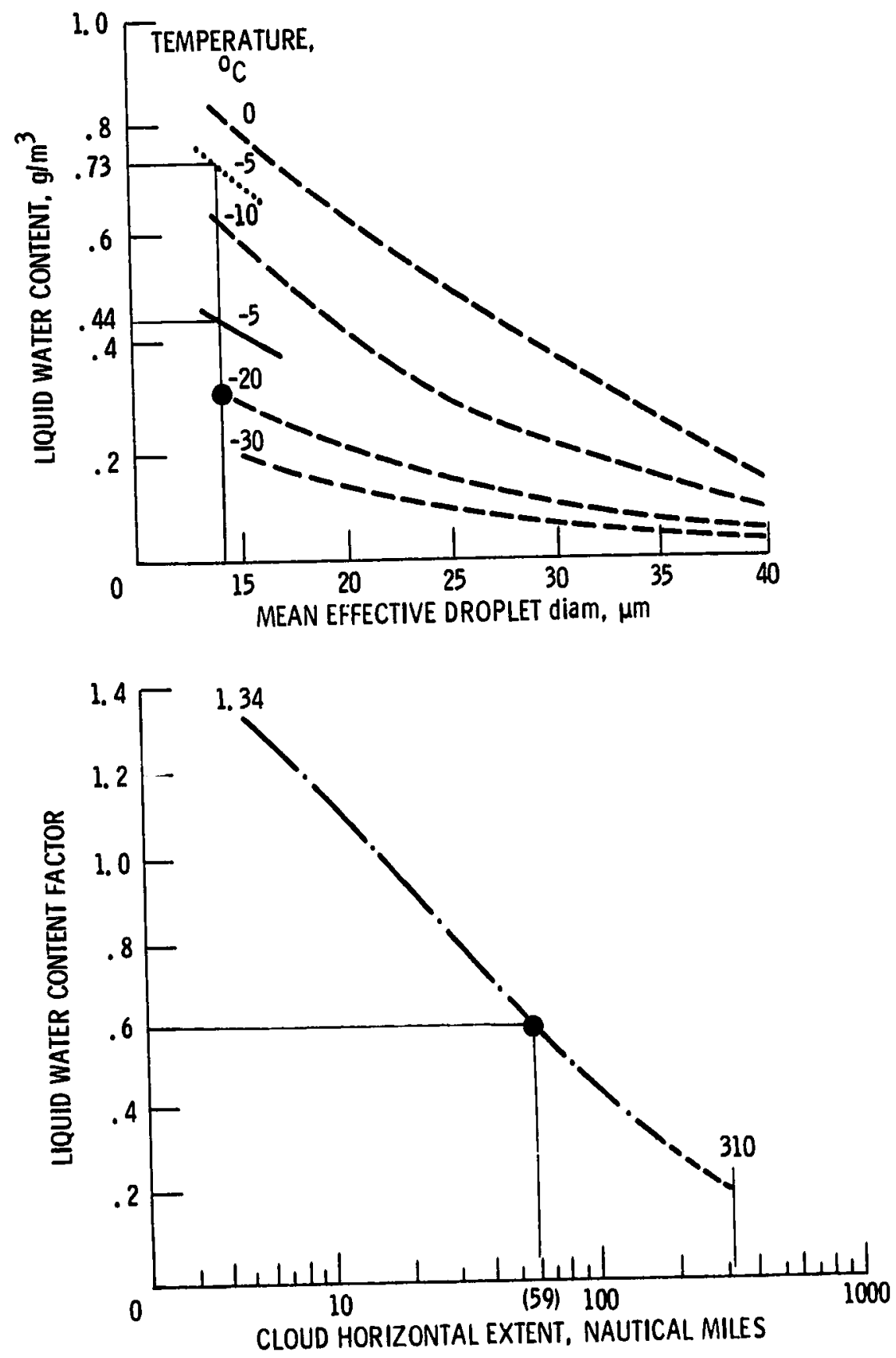

Figure 4b. - Flight 83-10 superimposed on FAR appendix $C$ of part 25 continuous maximum (stratiform clouds). 
ORIAt?:

OF POU: $\quad \ldots \ldots$.
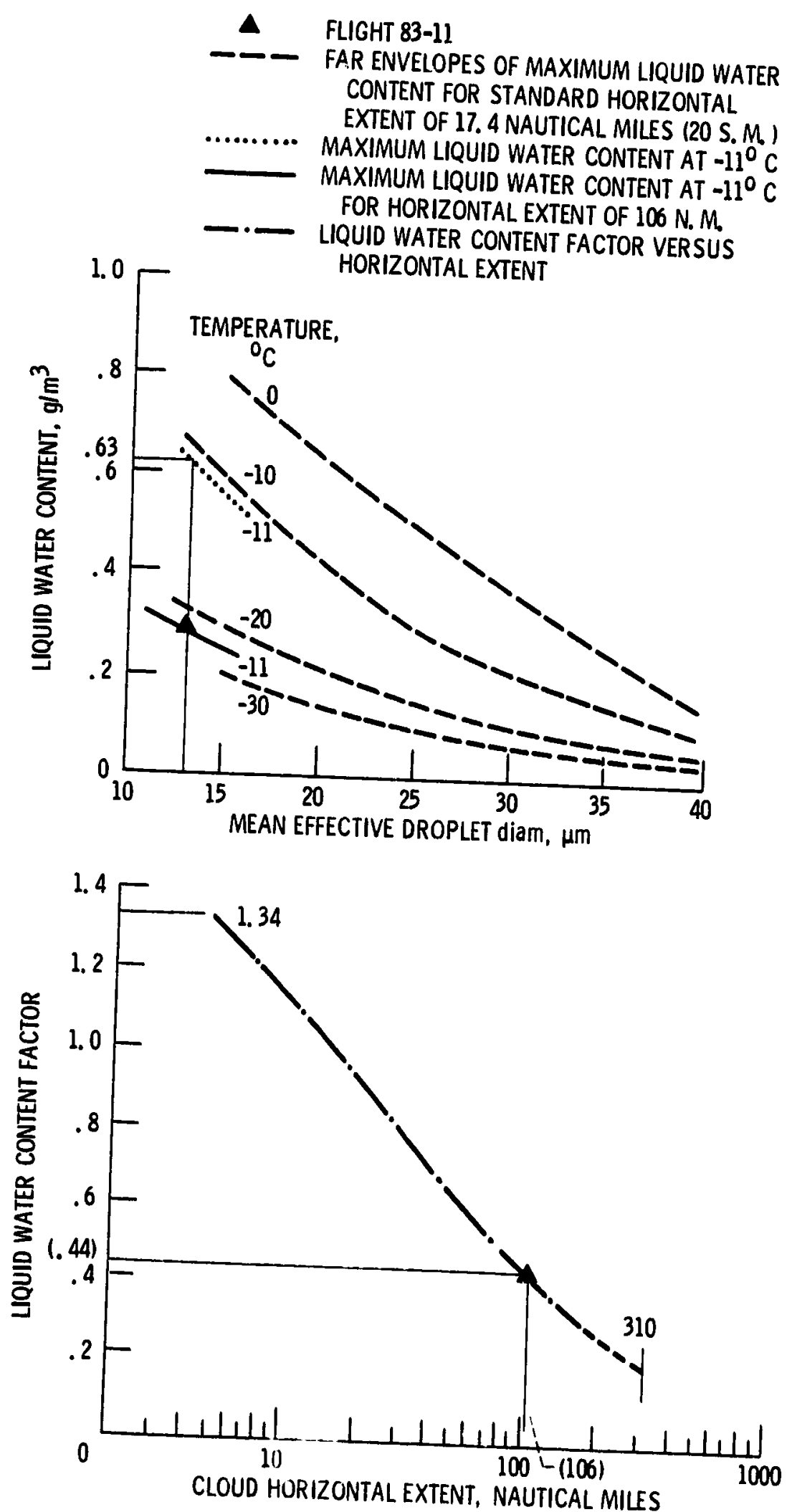

Figure 4c. - Flight 83-11 superimposed on FAR appendix $C$ of part 25 continuous maximum (stratiform clouds). 

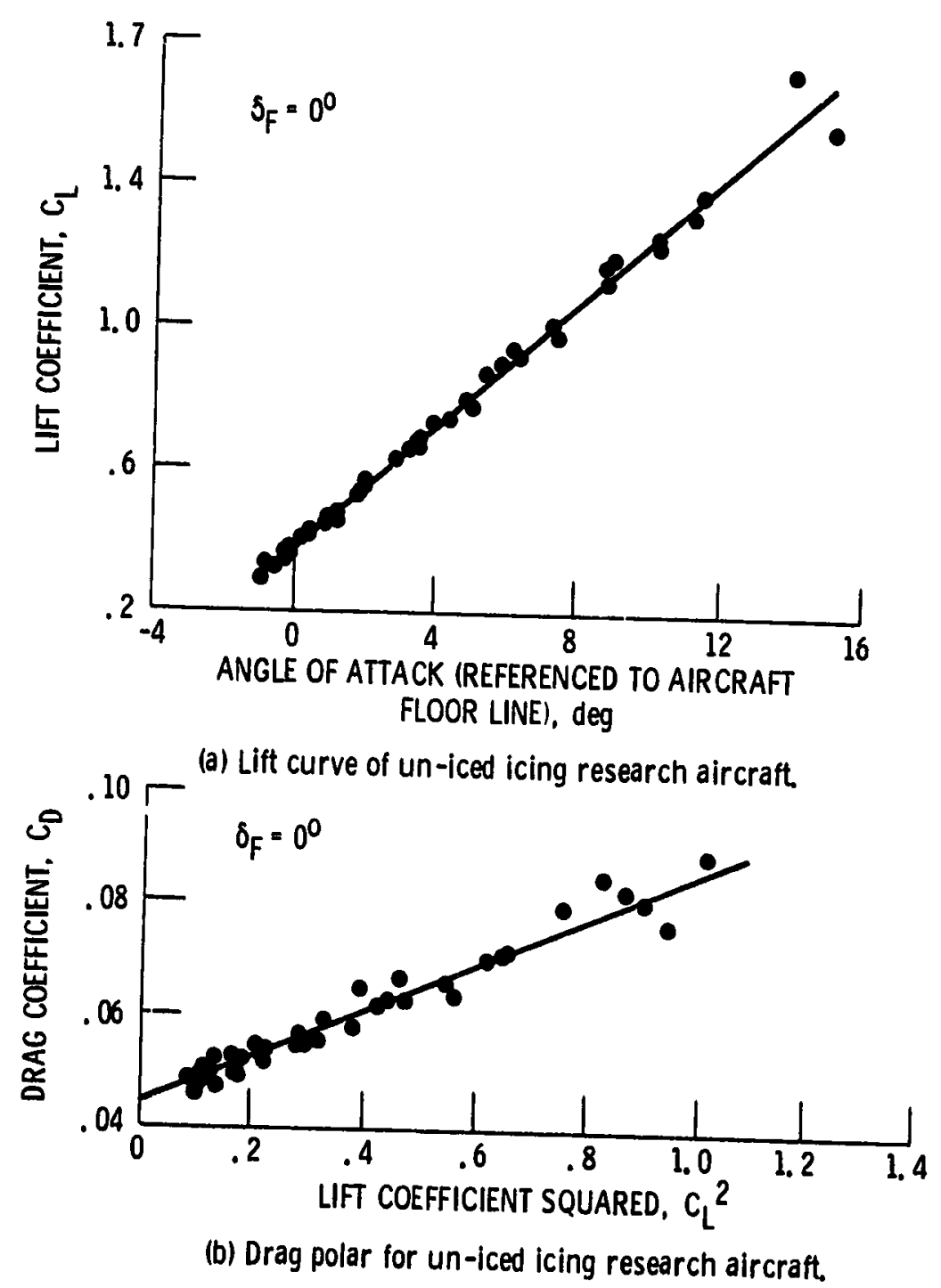

Figure 5. - Un-iced icing research aircraft performance. (Baseline.) 
OrR?:?

OF POCH QUALITY

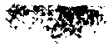

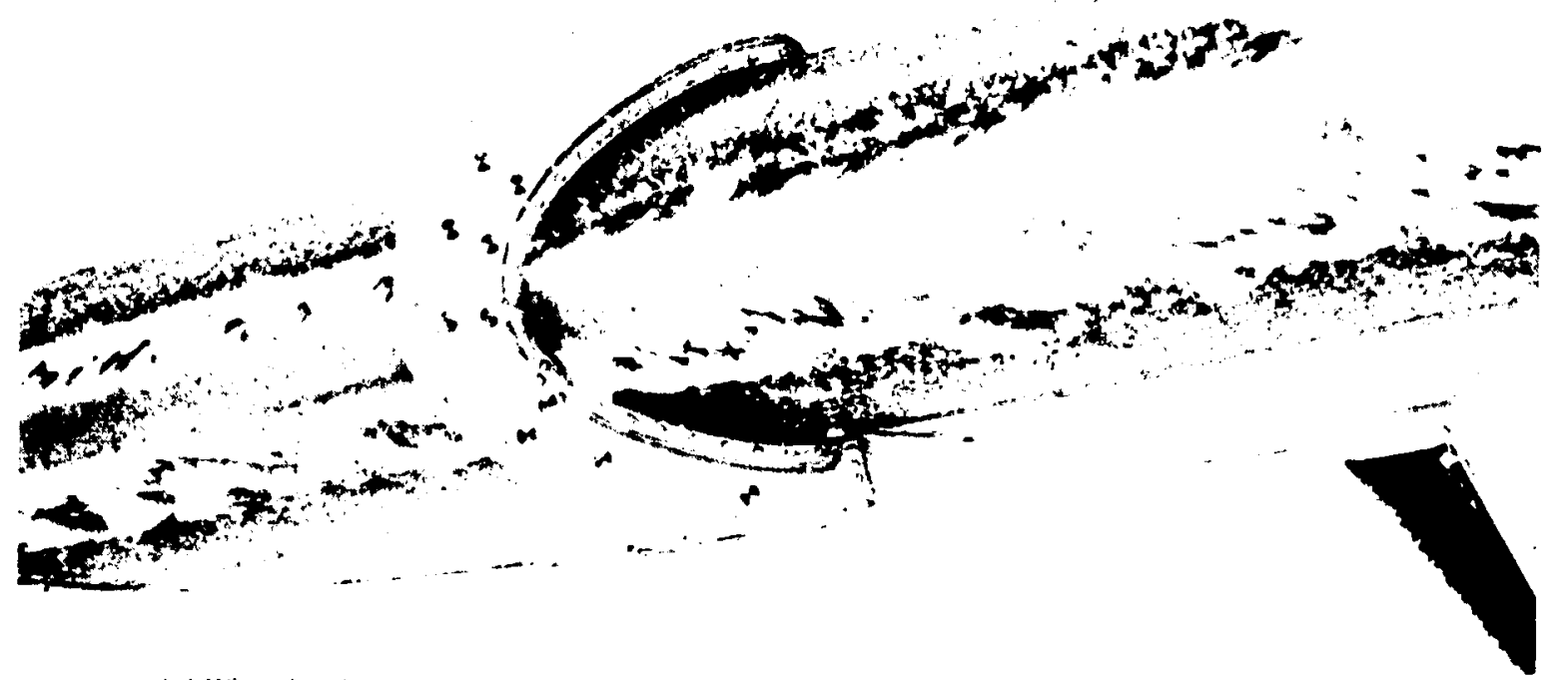

(a) Wing leading edge ice for mation taken at time of aircraft performance measurements.

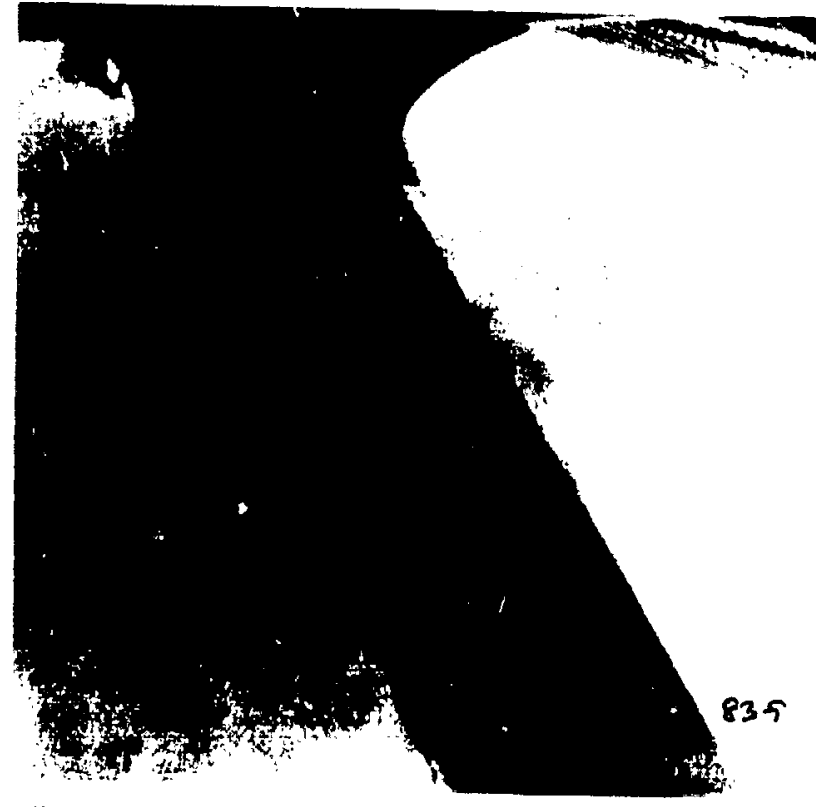

(b) Ice for mation on wing strut taken at time of aircraft perior mance measurements.

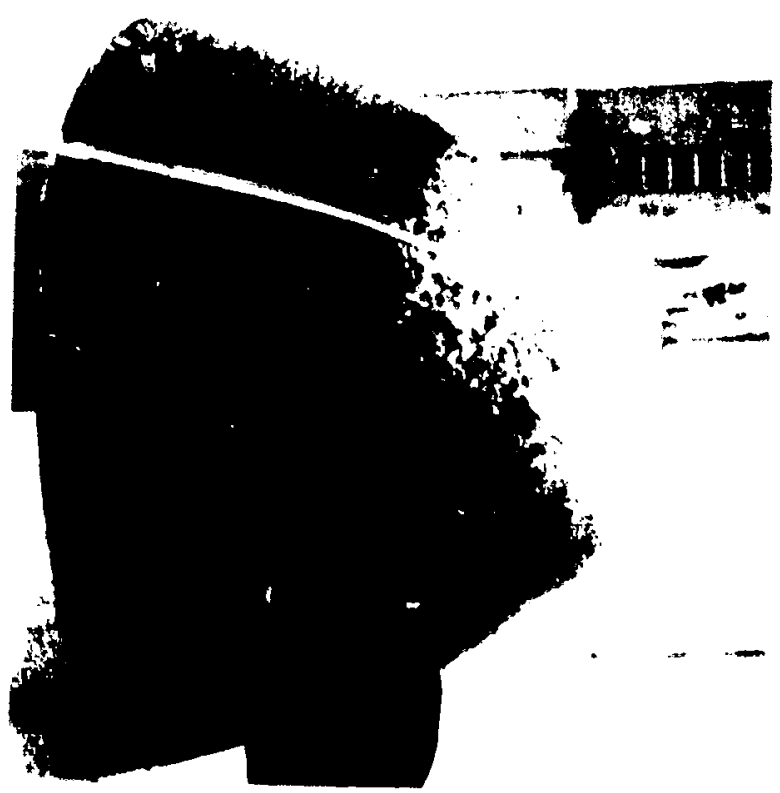

(c) Ice formation on radome taken after landing.

Figure 6. - Flight 83-9, glaze icing photographs. 


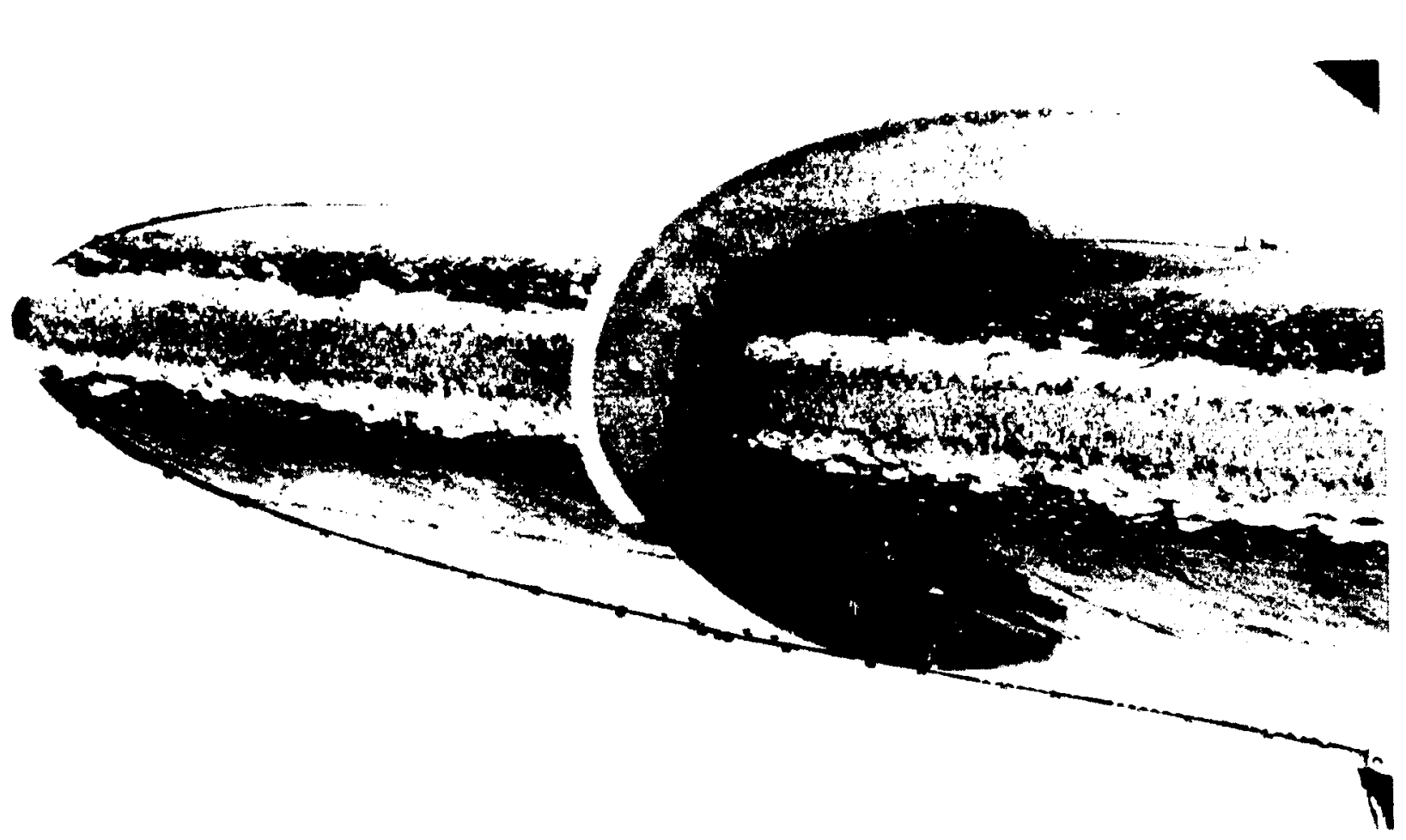

(a) Wing leading edge ice for mation taken at time of aircraft performance measurements.

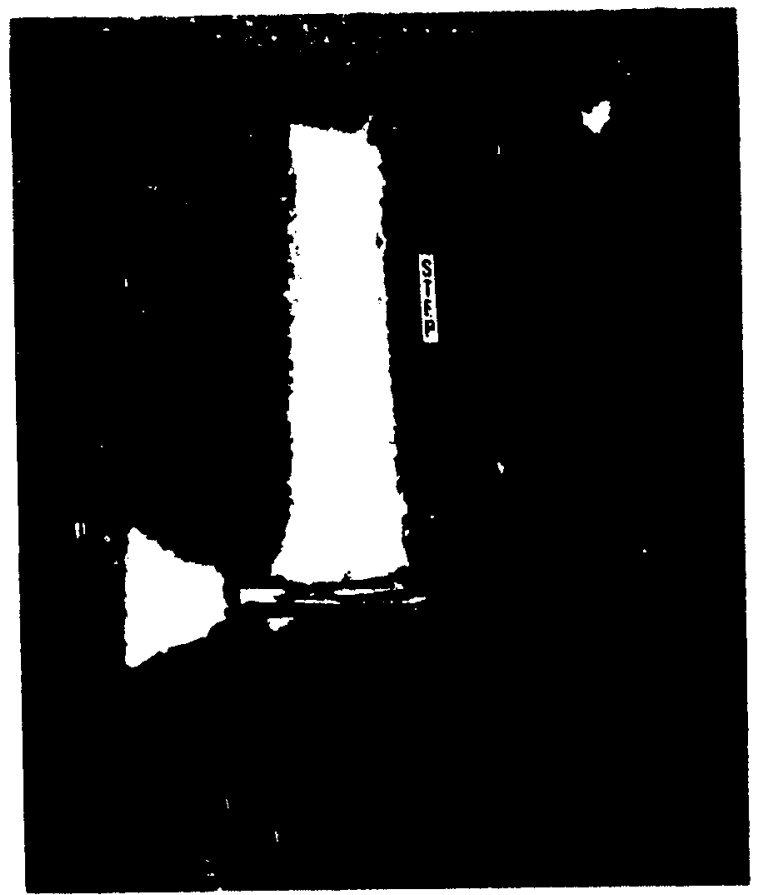

(b) Ice for mation on cockpit entry step taken after landing.

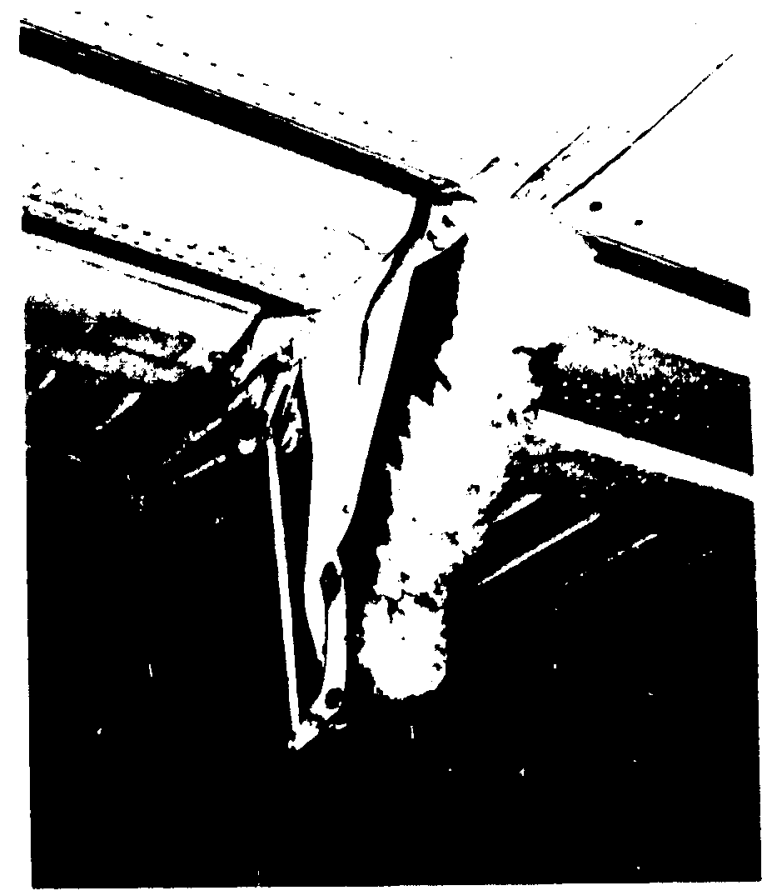

(c) Ice for mation on aileron hinge bracket taken after landing.

Figure 7. - Flight 83-10, glaze icing photographs. 


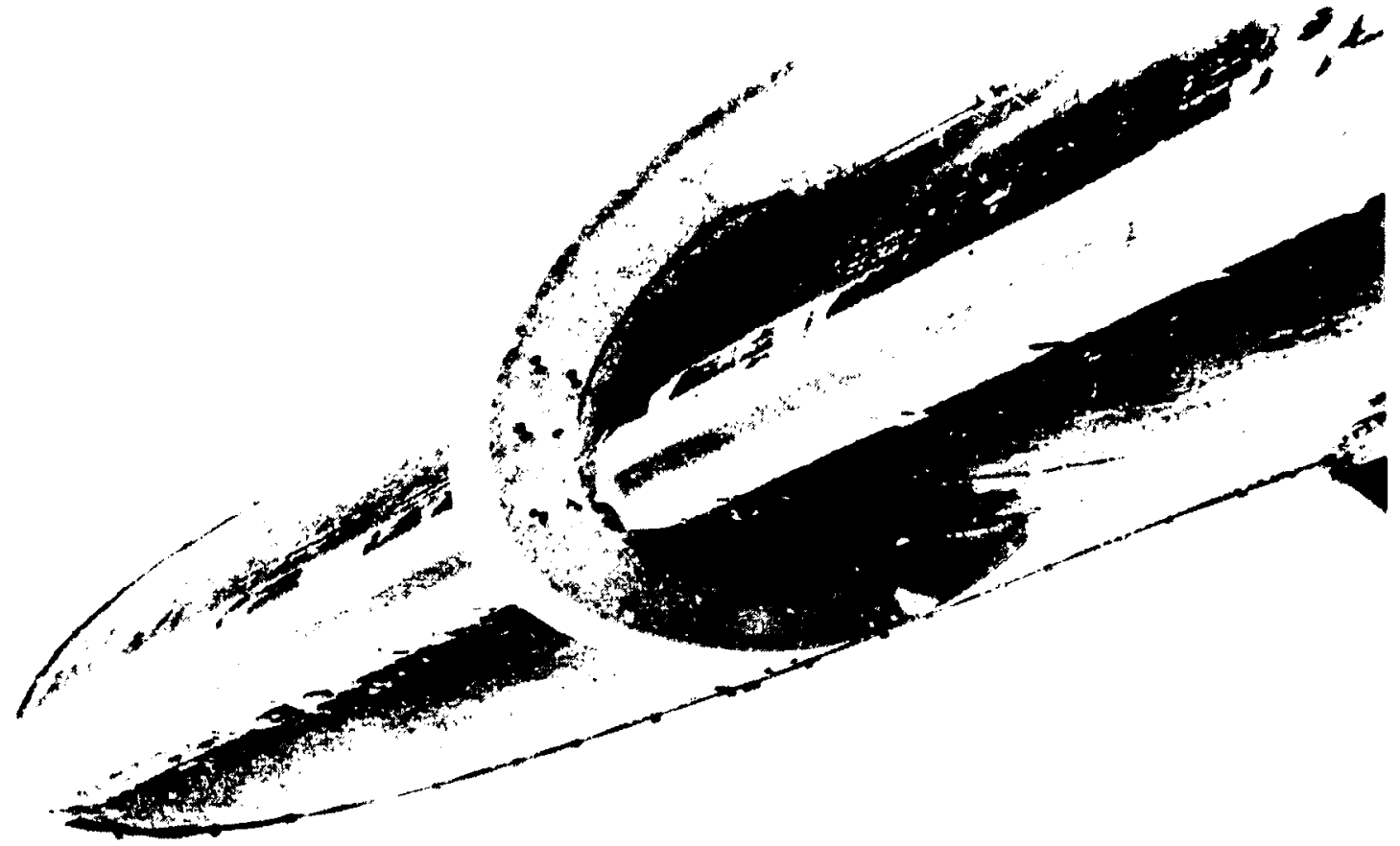

(a) Wing leading edge ice for mation taken at time of aircraft performance measurements.
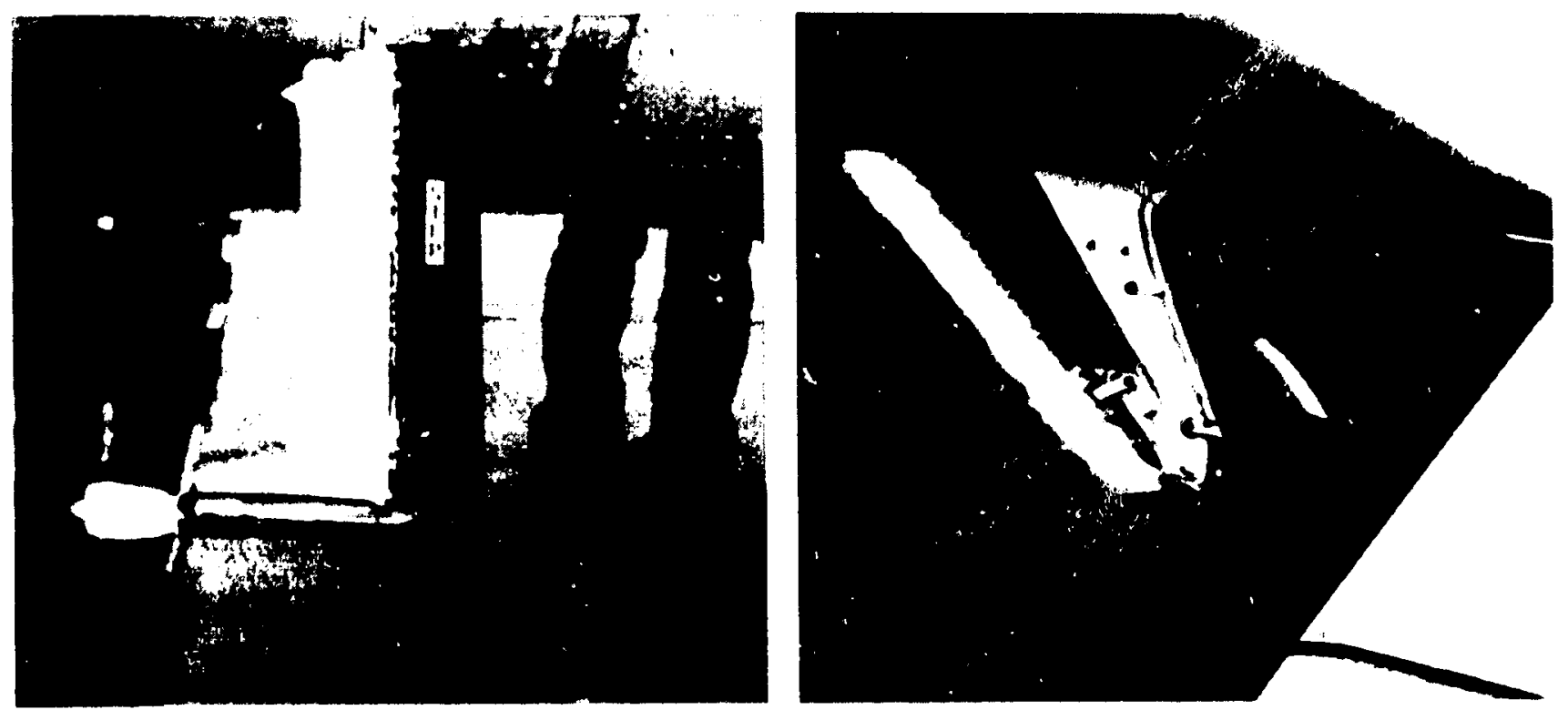

(b) Ice for mation on cockpit entry step taken after landing.

(c) Ice formation on aileron hinge bracket taken after landing.

Figure 8. - Flight 83-11, rime icing photographs. 


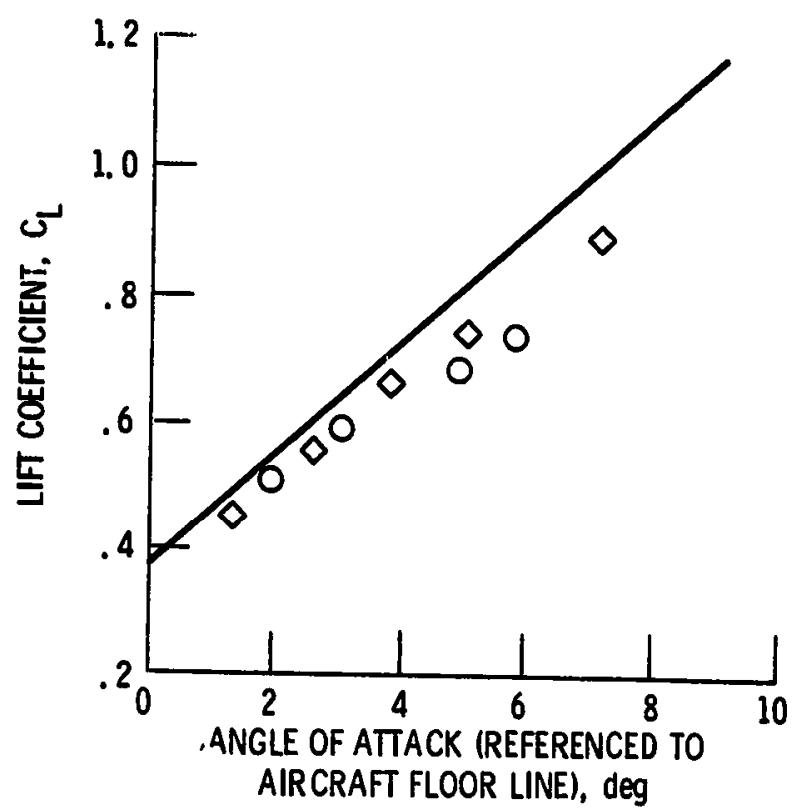

(a) Variation of aircraft $C_{L}$ versus $a_{\text {。 }}$

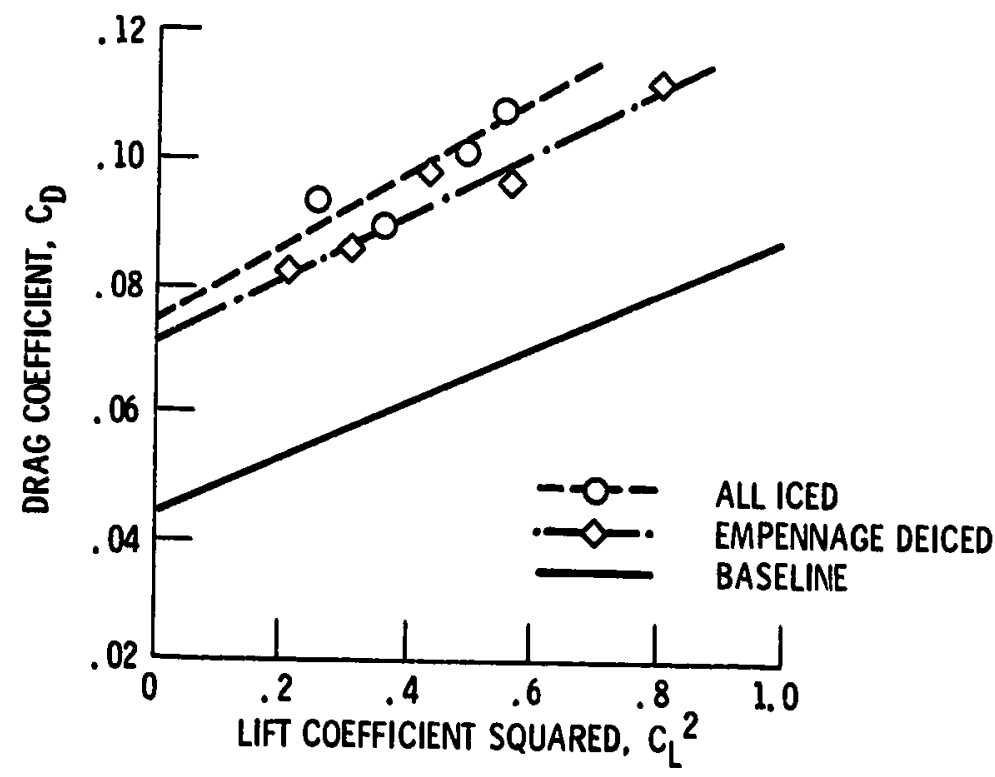

(b) Shift in aircraft drag polar.

Figure 9. - Flight 83-9, effect of heavy glaze icing on aircraft lift curve and drag polar as compared to the un-iced baseline. $\delta_{F}=0^{\circ}$. 
ORIER: : !

OF POOR Qunility

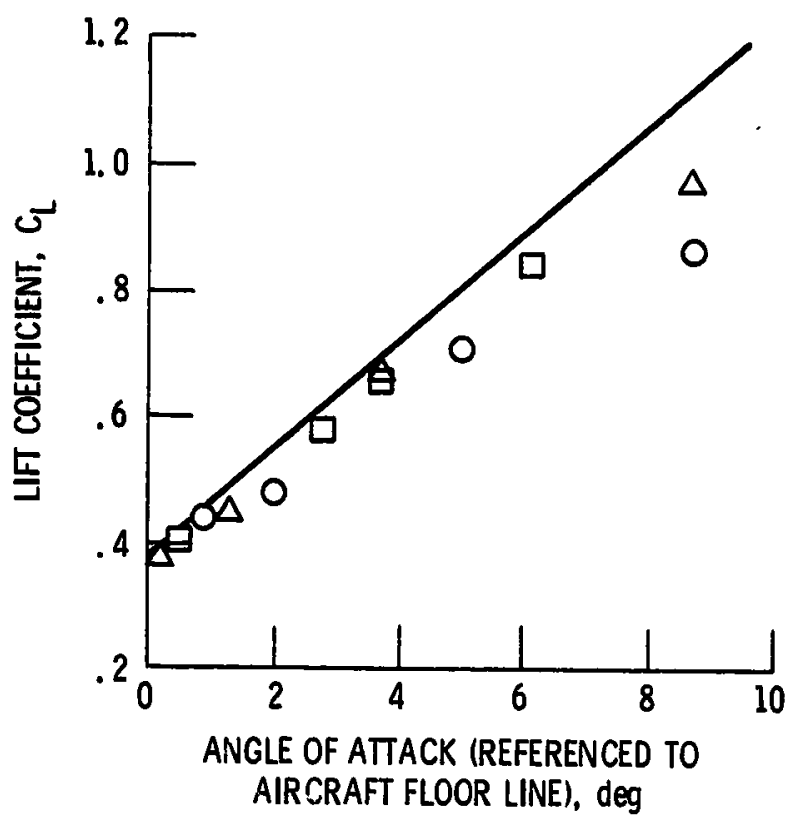

(a) Variation of aircraft $C_{L}$ versus a.

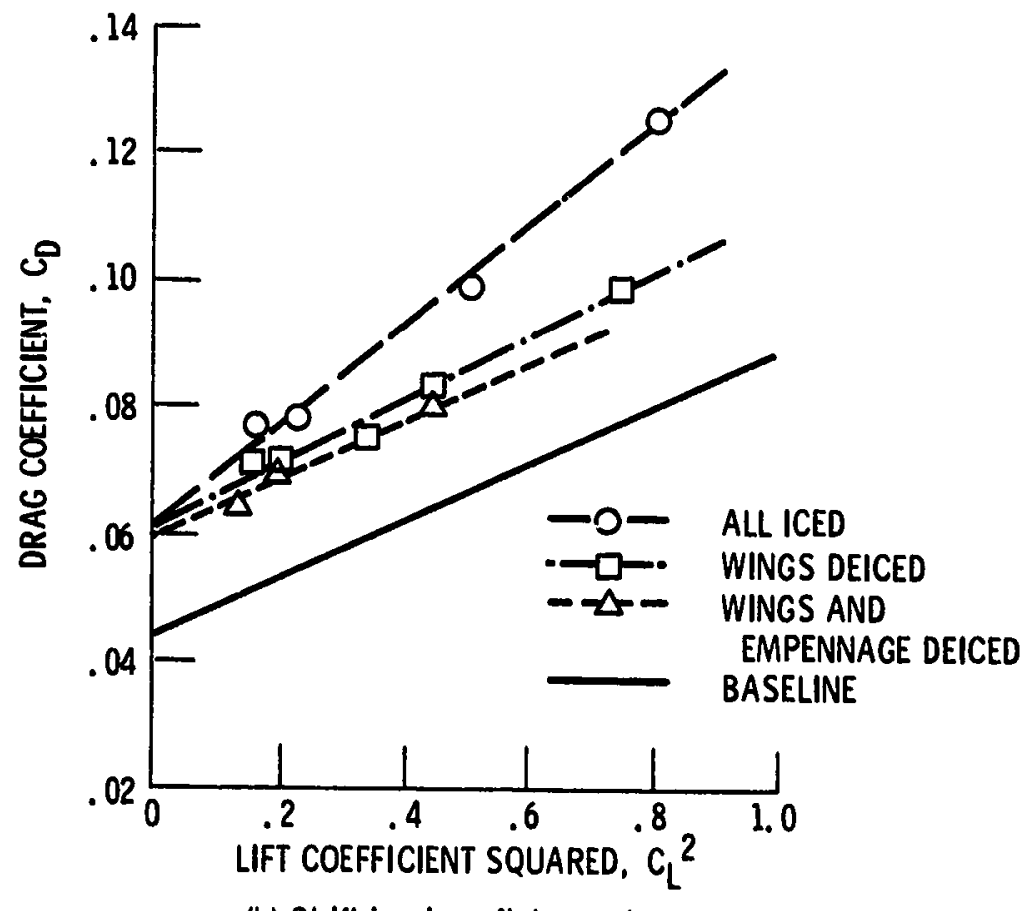

(b) Shift in aircraft drag polar.

Figure 10. - Flight 83-10, effect of glaze icing on aircraft lift curve and drag polar as compared to the un-iced baseline. $\delta_{F}=0^{\circ}$. 


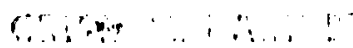

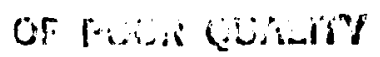

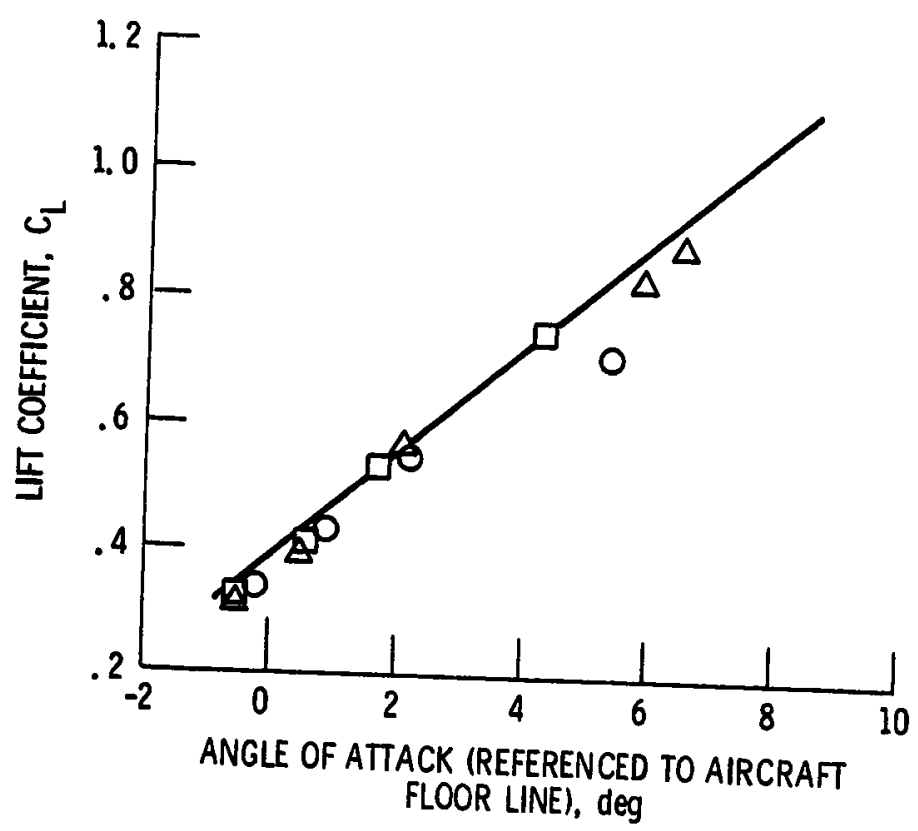

(a) Variation of aircraft $C_{L}$ versus $a_{\text {. }}$

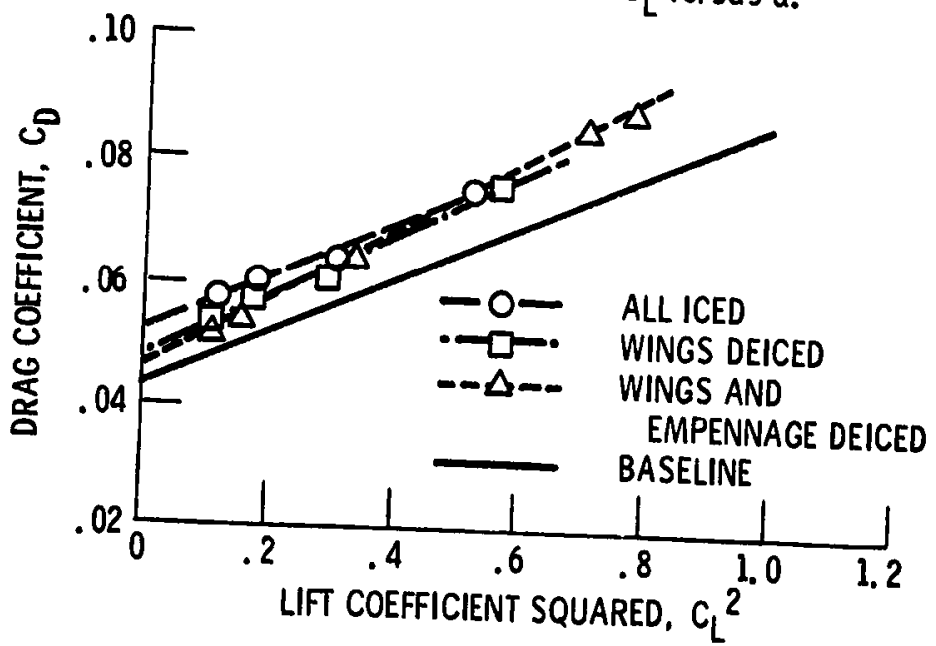

(b) Shift in aircraft drag polar.

Figure 11. - Flight 83-11, effect of rime icing on aircraft lift curve and drag polar as compared to the un-iced baseline. $\delta_{F}=0^{0}$. 
Orivisedry

OF PCLi: : : : :

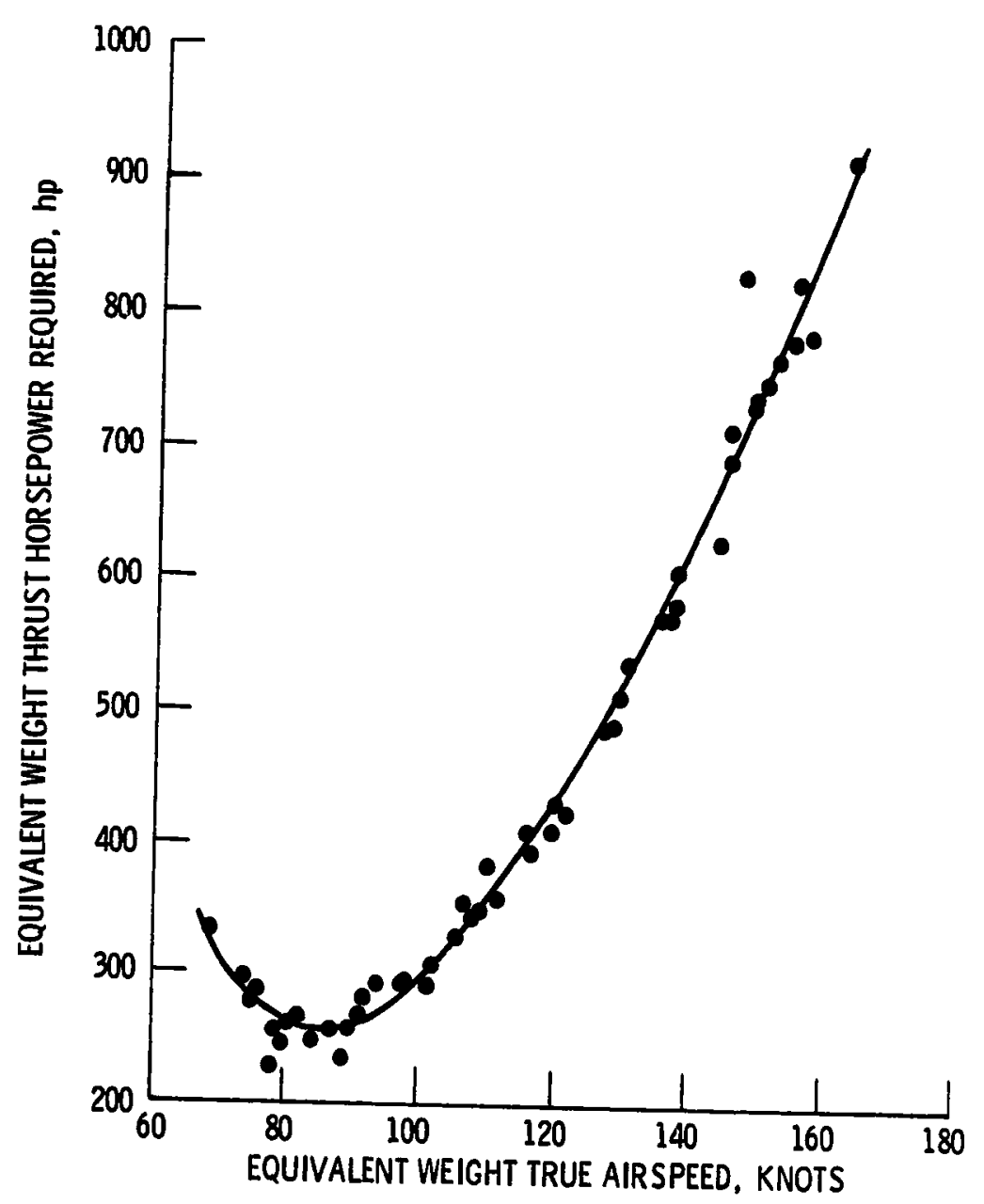

Figure 12. - Thrust horsepower required as a function of velocity for the un-iced aircraft. Flight test data corrected to standard day, seo level, and standard weight conditions; $\delta_{F}=0^{\circ}$. (Baseline.) 


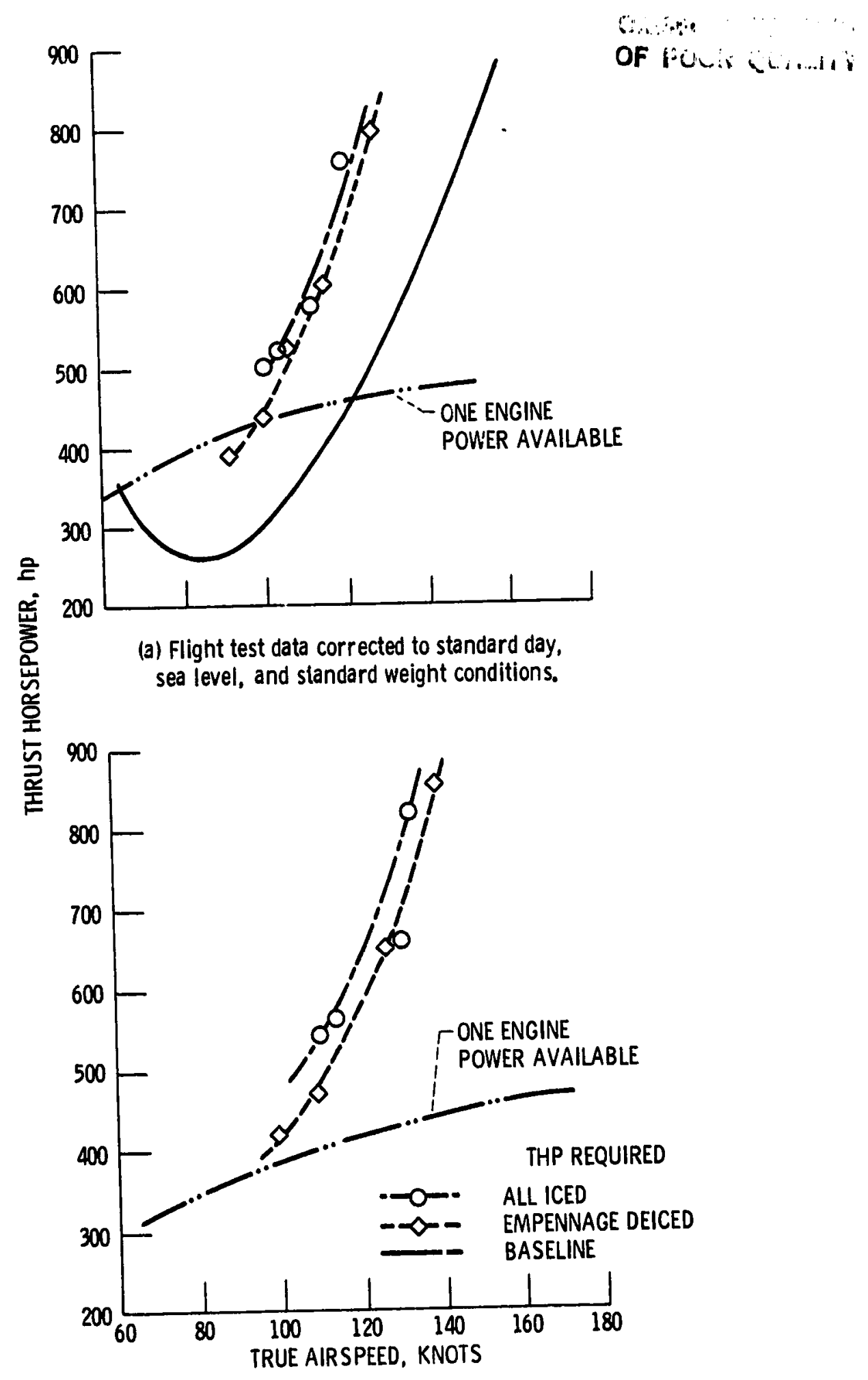

(b) Test conditions at $6000 \mathrm{ft}$ Flight test data corrected to standard weight only.

Figure 13. - Flight 83-9, effect of heavy glaze icing on thrust horsepower required relative to calculated one-engine thrust horsepower available. $\delta_{F}=0^{0}$. 


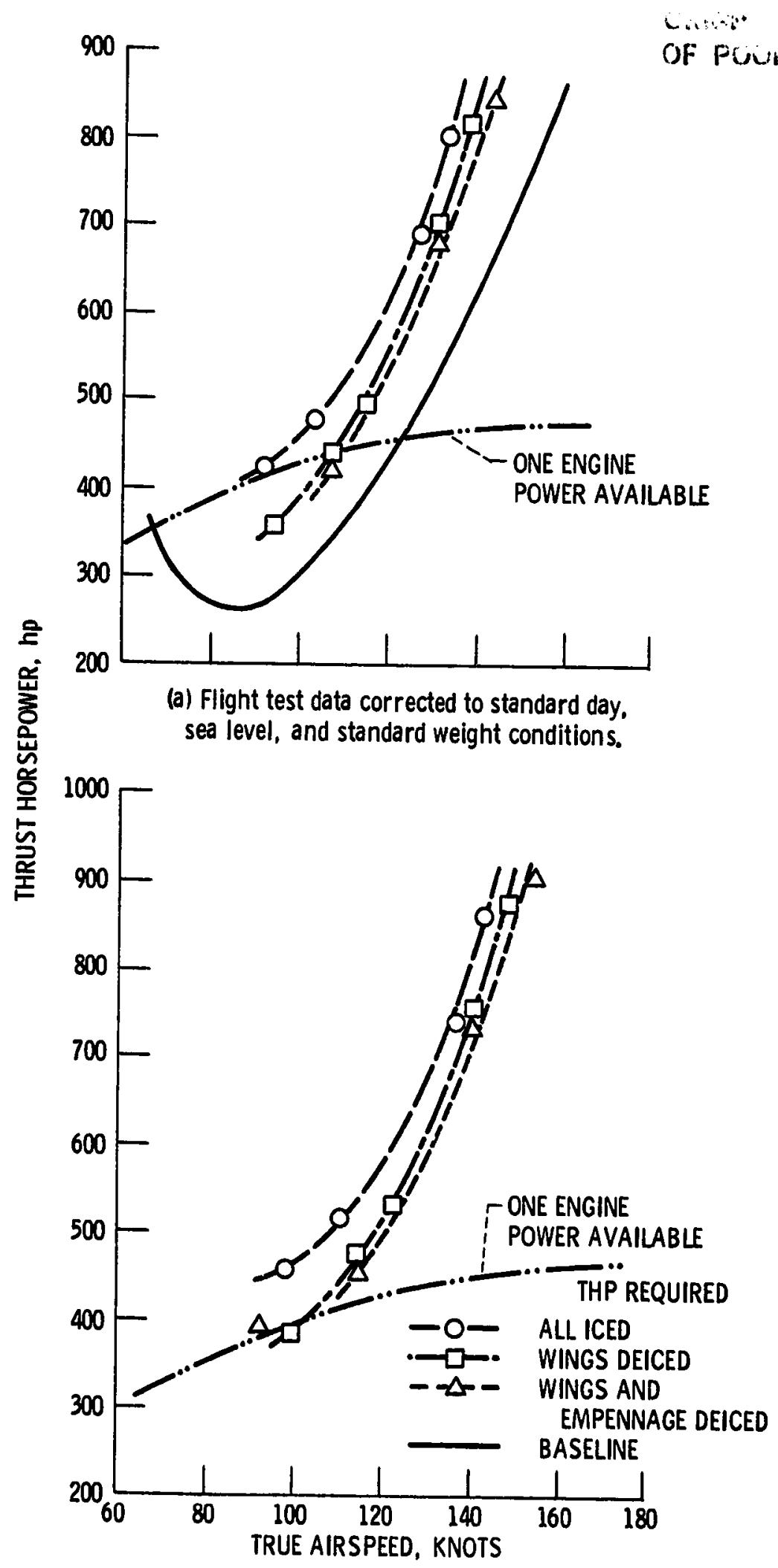

(b) Test conditions at $6000 \mathrm{ft}$ Flight test data corrected to standard weight only.

Figure 14. - Flight 83-10, effect of glaze icing on thrust horsepower required relative to calculated one-engine thrust horsepower available. $\delta_{F}=0^{0}$. 


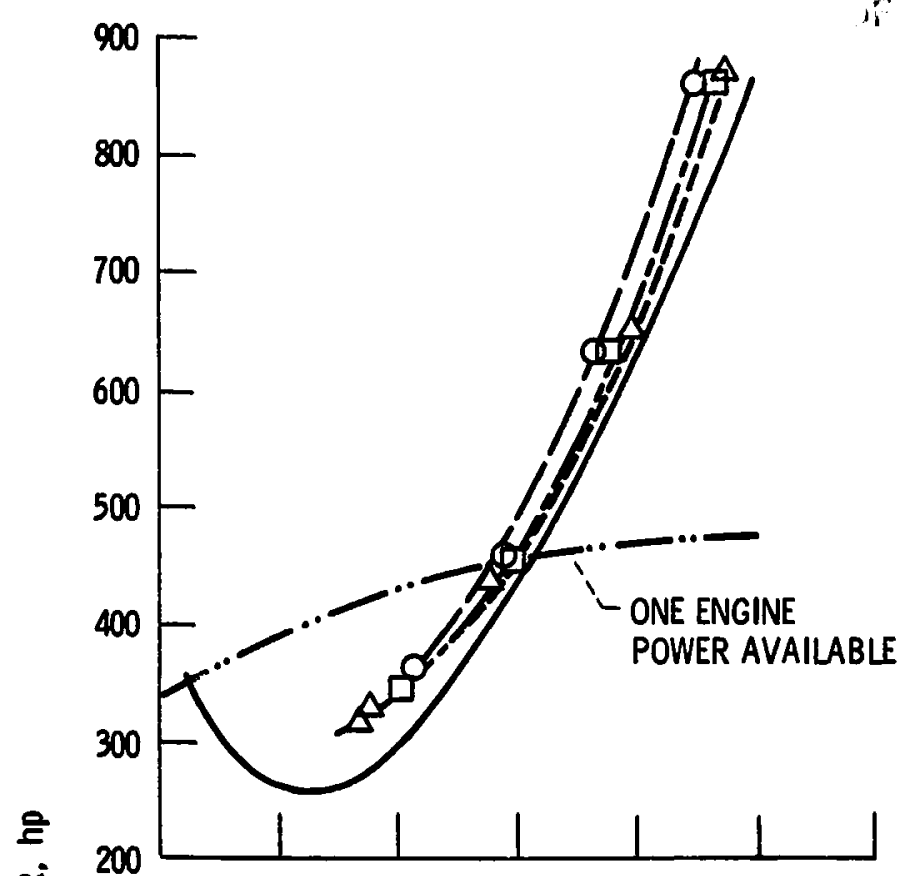

(a) Flight test data corrected to standard day, sea level, and standard weight conditions.

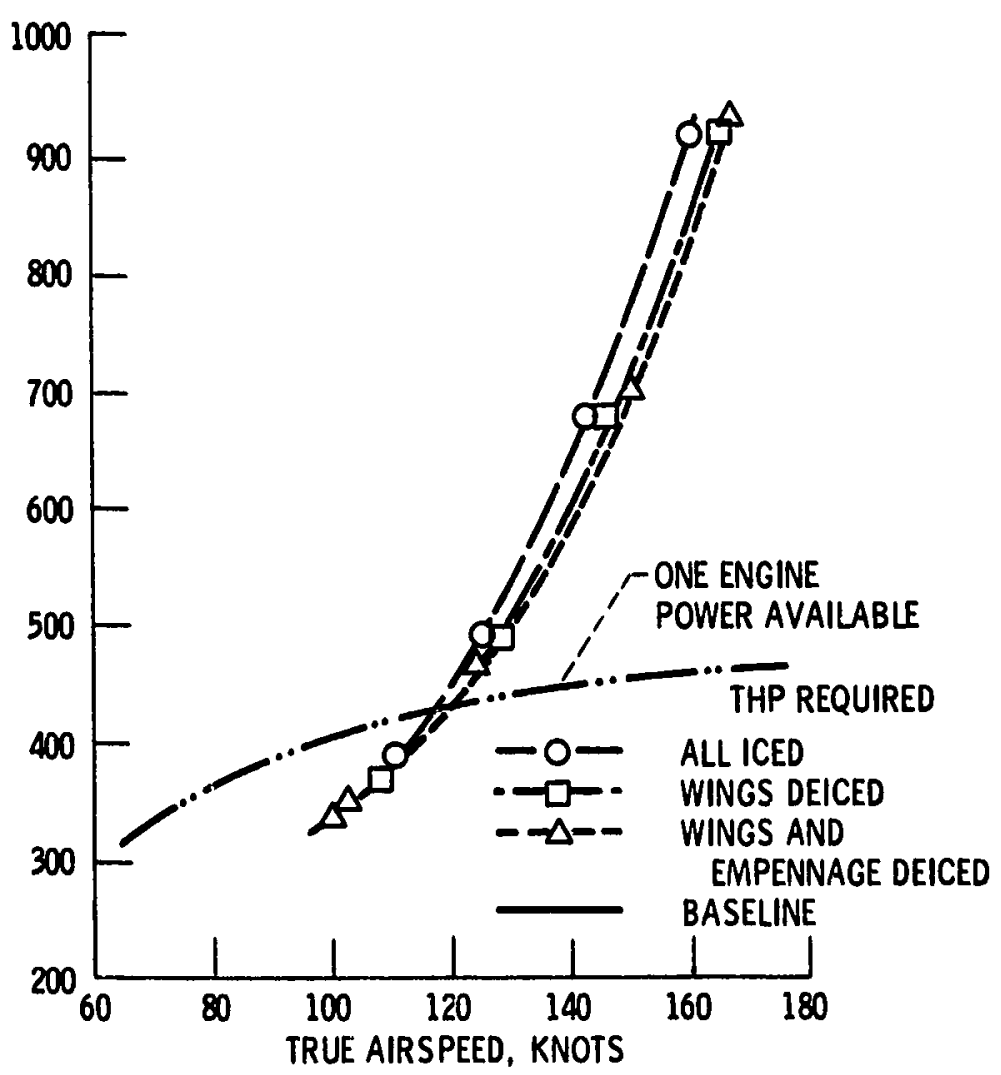

(b) Test conditions at $6500 \mathrm{ft}$. Flight test data corrected to standard weight only.

Figure 15. - Flight 83-11, effect of rime icing on thrust horsepower required relative to calculated one-engine thrust horsepower available. $\delta_{F}=0^{0}$. 